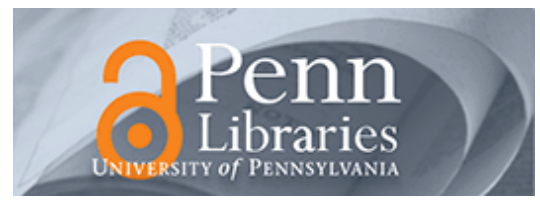

University of Pennsylvania

ScholarlyCommons

Accounting Papers

Wharton Faculty Research

2011

\title{
Hedge Funds: Pricing Controls and the Smoothing of Self- Reported Returns
}

Gavin Cassar

University of Pennsylvania

Joseph Gerakos

Follow this and additional works at: https://repository.upenn.edu/accounting_papers

Part of the Accounting Commons

\section{Recommended Citation}

Cassar, G., \& Gerakos, J. (2011). Hedge Funds: Pricing Controls and the Smoothing of Self-Reported

Returns. The Review of Financial Studies, 24 1698-1734. http://dx.doi.org/10.1093/rfs/hhq139

This paper is posted at ScholarlyCommons. https://repository.upenn.edu/accounting_papers/92

For more information, please contact repository@pobox.upenn.edu. 


\title{
Hedge Funds: Pricing Controls and the Smoothing of Self-Reported Returns
}

\author{
Abstract \\ We investigate the extent to which hedge fund managers smooth self-reported returns. In contrast to prior \\ research on the "anomalous" properties of hedge fund returns, we observe the mechanisms used to price \\ the fund's investment positions and report the fund's performance to investors, thereby allowing us to \\ differentiate between asset illiquidity and misreporting-based explanations. We find that funds using less \\ verifiable pricing sources and funds that provide managers with greater discretion in pricing investment \\ positions are more likely to have returns consistent with intentional smoothing. Traditional controls, \\ however, such as removing the manager from the setting and reporting of the fund's net asset value and \\ the use of reputable auditors and administrators, are not associated with lower levels of smoothing. With \\ respect to asset illiquidity versus misreporting, investment style and portfolio characteristics explain \\ $14.0-24.3 \%$ of the variation in our smoothing measures, and pricing controls explain an additional \\ $4.1-8.8 \%$, suggesting that asset illiquidity is the major factor driving the anomalous properties of self- \\ reported hedge fund returns. \\ Disciplines \\ Accounting | Business
}




\title{
Hedge Funds: Pricing Controls and the Smoothing of Self-Reported Returns ${ }^{*}$
}

\author{
Gavin Cassar \\ The Wharton School \\ University of Pennsylvania \\ Joseph Gerakos \\ Booth School of Business \\ University of Chicago
}

October 2009

We investigate the extent to which hedge fund managers smooth self-reported returns. In contrast with prior research on the "anomalous" properties of hedge fund returns, we observe the mechanisms used to price the fund's investment positions and report the fund's performance to investors, thereby allowing us to differentiate between asset illiquidity and misreporting-based explanations. We find that funds using less verifiable pricing sources and funds that provide managers with greater discretion in pricing investment positions are more likely to have returns consistent with intentional smoothing. Traditional controls, however, such as removing the manager from the setting and reporting of the fund's net asset value and the use of reputable auditors and administrators are not associated with lower levels of smoothing. With respect to asset illiquidity vs. misreporting, investment style and portfolio characteristics explain 14.0-24.3 percent of the variation in our smoothing measures and pricing controls explain an additional 4.1-8.8 percent, suggesting that asset illiquidity is the major factor driving the anomalous properties of self-reported hedge fund returns.

JEL Classification: G12, G23, M41, M42

Keywords: Hedge Funds, Performance Smoothing, Serial Correlation, Pricing Controls

\footnotetext{
* Corresponding author: Joseph Gerakos, 5807 S. Woodlawn Avenue, Chicago, IL 60637; telephone (773) 834-6882; email: jgerakos@chicagobooth.edu. Gavin Cassar, Steinberg Hall-Dietrich Hall (Suite 1300), 3620 Locust Walk, Philadelphia, PA 19104; telephone (215) 898-2023; e-mail; cassar@wharton.upenn.edu. The authors thank HedgeFundDueDiligence.com for providing the data used in the project. The authors also thank Ray Ball, Phil Berger, Alan Bester, John Core, Ralph DiMeo, Wayne Guay, Robert Krause, Doug Skinner, and brown-bag participants at the University of Chicago for their comments. This project benefited from the research assistance of Amy Chang and Jessica Leung. We appreciate financial support provided by The Wharton School and The University of Chicago Booth School of Business's Initiative on Global Markets.
} 
Several studies find substantial positive serial correlation in the self-reported monthly returns of hedge funds. Getmansky, Lo, and Makarov (2004) attribute this "anomalous" serial correlation either to funds holding illiquid assets in their portfolios or to the intentional smoothing of reported performance by hedge fund managers. Several recent studies further examine the statistical properties of hedge fund returns to determine the extent of intentional smoothing and misreporting (see, for example, Bollen and Pool 2008 and 2009, and Agarwal, Daniel, and Naik 2009). These studies confirm the anomalous properties of hedge fund returns across the various investment styles, but they observe neither the characteristics of the funds' portfolios nor the discretion that managers possess in the performance reporting process. Hence, the extent to which these anomalous properties are driven by intentional misreporting as opposed to illiquid assets remains an open empirical question.

This question is of economic importance because intentional smoothing can reduce the observed volatility of returns, thereby distorting commonly used risk adjusted performance measures such as Sharpe ratios and market betas. Fung et al. (2008) find that risk adjusted performance is a major determinant of hedge fund capital flows. Therefore, fund managers have incentives to increase their funds' observed risk adjusted performance because they receive a percentage of assets under management (Getmansky , Lo, and Makarov 2004). In addition, actions that delay the reporting of poor performance can decrease the likelihood that investors will immediately withdraw capital, thereby allowing a manager to continue collecting fees and to possibly benefit from future positive shocks to performance. Moreover, intentional smoothing can lead to wealth transfers among entering and exiting investors in the same way 
that stale prices can lead to wealth transfers among mutual fund investors (Boudoukh et al. 2002).

We investigate the association between hedge funds' pricing controls and the statistical properties of their self-reported returns. We define pricing controls as the mechanisms used to value, verify, and report the level and change in a fund's asset values. Some examples are the use of external parties to value individual investment positions, the use of external service providers to aggregate the values of individual investment positions to form the fund's official net asset value (NAV), and the use of reputable auditors. We posit that returns of hedge funds with more stringent controls over pricing, asset valuations, and reporting are less likely to have statistical properties that are consistent with manipulation after controlling for other fund characteristics such as investment style and portfolio characteristics.

To observe pricing controls and portfolio characteristics we use a proprietary database of hedge fund due diligence reports prepared by HedgeFundDueDiligence.com (HFDD). These reports provide an extensive array of detail regarding fund characteristics, pricing controls, reporting mechanisms, asset valuation mechanisms, and asset liquidity. We match these due diligence reports with the returns that the sample funds reported to the three largest commercial databases of hedge fund returns. Using these self-reported returns, we estimate three measures of smoothing and find that all three vary systematically with the discretion that fund managers possess in setting and reporting performance. In other words, some of the smoothness in reported returns can be explained by cross-sectional variation in the pricing controls that constrain the managers' discretion in pricing investment positions. 
We find that the returns are smoother for funds that provide managers with greater discretion in sourcing the prices used to value the fund's investment positions. For the various sources, we find the lowest level of serial correlation in the returns of funds that source prices primarily from exchange quotes, while we find the highest of levels of smoothing in the returns of funds that use either dealer quotes or prices determined by the manager.

We next examine the extent to which who prices the positions is associated with our smoothing measures. We find that returns are smoother for funds in which the manager prices investment positions with no external oversight. The economic magnitude of who prices on smoothed performance is, however, smaller than that of the pricing sources. Nevertheless, the smoothness of reported returns increases in the discretion that the manager possesses in reporting performance.

Finally, more reputable auditors and administrators are not associated with lower levels of smoothing. This finding is not surprising in the hedge fund setting given that the primary responsibility of the auditor is evaluating the fund's annual financial statement as opposed to evaluating the fund's monthly performance reports. We also do not find lower levels of smoothing in the returns of funds in which the manager is not involved in setting and reporting the fund's official NAV to investors. Overall, the reputation of those who calculate and review the fund's financial statements and NAV play a relatively smaller role in the reduction of misreporting in monthly returns than do the sources of prices and who prices the fund's investment positions.

With respect to the economic magnitude of intentional smoothing, we find that investment style and portfolio characteristics explain 14.0-24.3 percent of the variation in our 
three smoothing measures. Pricing controls explain an additional 4.1-8.8 percent, suggesting that asset illiquidity is the major factor driving the anomalous properties of self-reported hedge fund returns. Our findings are robust to varying the estimation periods and to examining the effects of controls within investment styles and other fund characteristics. We further corroborate our results by examining the distributions of self-reported monthly returns and find, consistent with intentional manipulation, that funds with either dealer-sourced or manager-provided prices are more likely to report slightly positive than slightly negative returns.

This study extends the hedge fund literature on anomalous return properties by estimating the magnitudes of intentional smoothing. Our estimates assist investors or researchers who use self-reported hedge fund returns to evaluate hedge fund investment opportunities and/or hedge funds as an asset class. Furthermore, recent research documents an illiquidity premium in hedge fund returns (see, for example, Aragon 2007, and Khandani and Lo 2009). These studies use the same smoothing measures to estimate the illiquidity of assets held in hedge fund portfolios. We provide insight into the extent that such an illiquidity premium is associated with the actual illiquidity of the fund's underlying assets as opposed to misreporting by hedge fund managers. Finally, by examining the extent of intentional smoothing, we inform the current debate about proposed changes in hedge fund regulation.

Furthermore, several features make hedge funds a powerful setting to investigate the effect of managerial valuation discretion on reported performance. First, prior research on the effectiveness of pricing controls is primarily limited to publicly traded firms for whom most pricing controls are mandated by regulation and generally accepted accounting principles 
(GAAP). In contrast, hedge funds exercise substantial discretion in the use and choice of explicit pricing controls and reporting mechanisms. Second, the managerial incentives to manipulate asset valuations and reported performance are far clearer in investment vehicles than in operating firms (Chandar and Bricker 2002). For example, all hedge fund managers have an incentive to undertake smoothing. In contrast, it is not clear whether all managers of operating firms have incentives to smooth (for a discussion, see Dechow, Ge, and Schrand 2009). We also contribute to the current debate on "mark to market" accounting by demonstrating how pricing controls affect the valuation of investment positions and highlighting the practical consequences of allowing managers to obtain from apparently objective sources, such as dealer quotes (Laux and Leuz 2009).

\section{Background}

\subsection{Hedge Fund Setting}

Hedge funds are managed investment vehicles. Some stylistic features of hedge funds include: they are often privately held, generally comprised of wealthy individuals and institutional investors, and typically organized in the U.S. as limited partnerships and offshore as corporations (Fung and Hsieh 1999). There has been substantial growth in the hedge fund industry, both in the number of funds and in assets under management (Brown, Goetzmann, and Ibbotson 1999; Fung and Hsieh 1999; Lo 2008).

Unlike other investment vehicles, hedge fund managers generally structure their funds to avoid reporting requirements imposed by regulators (Lhabitant 2008 page 405). For example, hedge funds are structured to be exempt from the periodic reporting obligations of the 
Securities Exchange Act of 1934, and the registration requirements of the Investment Company Act of 1940 (Oesterle 2008). Therefore, a more descriptive definition of a hedge fund is an investment fund exempt from a list of specific federal acts regulating investment vehicles (Oesterle 2008). This minimal regulatory environment provides hedge funds with substantially greater discretion in their operations, especially regarding the valuation and reporting of fund assets and performance, compared to regulated investment vehicles, such as mutual funds (McVea 2008b). For example, hedge funds are not required to have their assets independently valued (McVea 2008a).

The offering circular or "private placement memorandum" (PPM) documents the controls employed by the hedge fund to value and report the fund's performance to investors. In addition to these controls, the PPM and the subsequent executable limited partnership and subscription agreements lay out other fund operations and the investor's contractual rights including: the fees agreed to be paid, the terms under which the investor can invest and withdraw funds, and the investor's ability to monitor the fund (ABA 2005 pages 96-98). Given that hedge funds are substantively exempt from securities regulations, the terms provided in the PPM and subsequent executable agreements represent virtually all of the pricing controls in place for the investor's hedge fund investment.

\subsection{Anomalous Properties of Hedge Fund Returns}

Recent research documents unusual properties in reported hedge fund returns. Below we provide a brief overview of the key findings from this research. A critical feature of this research is the extent to which research designs can distinguish opportunistic manipulation 
from explanations related to the fund's underlying investment style, the manager's skill, and/or the illiquidity of the fund's investment positions.

Asness, Krail, and Liew (2001) argue that hedge fund managers can reduce estimates of fund exposure to systematic risk by exploiting the flexibility they possess in valuing assets at month-end. Specifically, by using stale prices in setting the fund's NAV, a manager can reduce estimates of the fund's market beta and increase the smoothness of the fund's return series. When they include both current and lagged S\&P 500 Index returns in a simple market model regression, they find substantially higher systematic risk exposure in hedge fund returns than when they only include the current month's S\&P Index return. They interpret this evidence as consistent with either the illiquidity of the fund's assets or misreporting by fund managers.

Getmansky, Lo, and Makarov (2004) develop a model of smoothed returns to explain cross-sectional variation in serial correlation in reported hedge fund returns. They observe the highest serial correlation in investment styles that typically invest in illiquid assets.

Furthermore, they use simulations to rule out alternative explanations for serial correlation that are related to time varying expected returns, time varying leverage, and high water marks in incentive fees. Given that they lack fund-level information about accounting conventions and operational structure, they are unable to distinguish between serial correlation being driven by the underlying illiquidity of the assets or intentional smoothing by fund managers.

Bollen and Pool (2008) attempt to distinguish between the manipulation and illiquidity explanations of smoothing by using a serial correlation measure that allows for varying effects of good and bad news. Specifically, they present a model in which a fund manager fully reports gains but delays reporting losses, thereby leading to conditional serial correlation in reported 
risk-adjusted returns. Consistent with fund managers possessing incentives to report good news and delay bad news they find empirical evidence of conditional serial correlation. Further, they find mixed evidence that the observed serial correlation varies by whether the fund has been audited or not. Nevertheless, they do not control for the underlying liquidity of funds' asset portfolios and do not observe the discretion that managers possess in reporting performance.

Our study extends prior research on hedge fund return smoothing by examining whether the association between pricing controls and reported returns is consistent with intentional manipulation. Furthermore, our data allow us to distinguish between asset illiquidity-based explanations and misreporting-based explanations for the anomalous properties in reported hedge fund returns. Consequently, we can directly investigate how managerial discretion in pricing controls affects the properties of hedge fund returns.

\subsection{Pricing Controls}

We define pricing controls as mechanisms used to value, verify, and disclose the level and change in a fund's investment positions and official NAV. We classify pricing controls into four categories. The sources of prices used to value the fund's investment positions comprise the first category. The second category consists of who prices the individual investment positions. The third relates to who calculates and reports the portfolio's NAV to investors. The fourth category relates to the reputation of the service providers who prepare and review the valuations provided to fund investors.

Hedge funds obtain periodic valuations of their investment positions from several sources. Common sources include exchanges and Over-The-Counter (OTC) markets, whereby 
valuations are based on market prices, such as the last trade or a function of the most recent bid and ask. Hedge funds can also obtain values based on quotes solicited from dealers. The practitioner literature suggests that even for hard to value assets, such as complex and illiquid assets, many hedge funds obtain prices from market-based and dealer-based quotes (MFA 2009). Hedge funds can also determine valuations by using proprietary financial models and internally generated prices, whereby fund managers, themselves, determine the value of investment positions (President's Working Group 2008 page 47). Internally generated prices allow managers to exercise professional judgment and to incorporate all available information into the asset valuation. This approach, however, provides managers with the greatest opportunity to manipulate asset values.

Practitioner surveys show that no one method has emerged as a dominant methodology for any asset class and that there is substantial heterogeneity in the pricing of similar assets across various hedge funds (Deloitte 2007 page 16). The source of prices is an important issue in the valuation process. For example, the Alternative Investment Management Association found that 41 percent of surveyed hedge fund managers, service providers, and investors regard pricing sources as the main challenge to pricing investment assets (AIMA 2005 page 6).

Hedge funds also possess discretion with respect to who obtains the values for the funds' investments. The simplest approach is for the fund manager to obtain the prices for each investment position. In practice, however, the majority of hedge funds employ external services to value their investment positions. These external services can be used exclusively to price the portfolio without any intervention from the fund manager. As an alternative, a fund manager can collaborate with an external pricing service to value investment positions. Finally, some 
hedge funds employ multiple external entities to value investment positions. Industry best practice is for independent external service providers to value the fund's investment positions (AIMA 2005 page 7; Deloitte 2007 page 16; President's Working Group 2008).

The entity that sets and reports the fund's official NAV to investors can differ from the entity that prices the individual investment positions. Pricing is done on a position by position basis; while NAV is determined by aggregating the prices of the individual investment positions. While pricing takes place on a regular and frequent basis, the NAV is typically estimated and reported to investors monthly. The most objective approach is to remove the manager from determining and reporting the fund's official NAV (President's Working Group 2008). Nevertheless, some funds allow the manager to calculate and report the NAV alone, while other funds opt for a collaborative approach with a third party, usually an administrator. The final category of pricing controls consists of the quality and reputation of the fund's service providers, specifically its auditor and administrator. Similar to engagements with publicly traded firms, auditors undertake annual audits of hedge funds to ensure that the financial information provided to investors complies with the relevant accounting standards. The role of fund administrators varies substantially across engagements. They typically provide back-office support, such as performing day-to-day administrative operations and accounting and valuation services, and serving as the interface with investors (SEC 2003 page 56). In many cases the administrator also calculates the NAV using data provided by either the fund's custodian or prime broker (Lhabitant 2008). We posit that hedge fund third party service providers with valuable reputations have incentives to reduce financial misstatements and returns manipulation. 
We posit that more extensive pricing controls decrease the bias and increase the precision of asset valuations and reported returns made to hedge fund investors. The use of external parties and objective sources to value investment positions and the use of independent and reputable service providers to report and verify the NAV provide the most objective measurements of fund performance, thereby reducing the likelihood of manipulation. Therefore, we posit that hedge funds with these more stringent pricing controls are less likely to have returns consistent with manipulation, namely have lower levels of serial correlation and smoothing in their self-reported returns.

Nevertheless, there are several institutional features that can limit the ability of pricing controls to reduce deliberate smoothing of reported returns. For example, while exchange and market-based quotes are generally appropriate for liquid assets, the use of market-based sources for thinly traded and hard-to-value assets is more problematic and can result in unreliable estimates (Deloitte 2007 page 15). In less liquid or thinly traded markets, such as over-the-counter markets, the practitioner literature documents how investment managers can manipulate reported performance through the strategic selling of assets around periods of valuation (Spurgin 2001; Weisman 2002). Hence, some assets are likely to be susceptible to manipulation, regardless of the objectivity of the pricing control in effect.

For example, the use of dealers to provide valuations can allow managers to "dealer shop," i.e., approach various dealers for quotes and employ the quote that is most consistent with the fund manager's objectives or request and receive a desired quote from the fund's dealer (Scholtes and Tett 2007). Even valuation models that appear mechanical and, therefore, not open to opportunism can rely on assumptions that suppress volatility and induce 
smoothing (Skeel and Partnoy 2007). Furthermore, the repeated use of the same valuation methodology month after month can consistently understate the volatility of returns associated with the invested asset (McVea 2008a page 11).

The ability of service providers, such as administrators and auditors, to prevent or detect opportunistic smoothing in monthly returns is likely to be limited by the scope and focus of their duties. For example, many auditors of hedge funds do not review how funds value their investment positions (Lhabitant 2008 page 105). When auditors do review how funds value their assets, the sampling tests are less comprehensive than the standards for registered investment companies (SEC 2003 page 66). Furthermore, the audit engagement typically focuses on the accuracy of financial year end valuations, rather than on the month-to-month valuations. Consistent with audits only affecting year end returns, Bollen and Pool (2009) report that manipulation of reported returns is more likely in months not surrounding an audit. In addition, while the practitioner literature strongly advocates against allowing fund managers to perform final valuations or to communicate their valuations to an administrator (Lhabitant 2008 page 100), some authors suggest that for assets with no simple or accepted valuation approach, administrators often accept the valuation provided by the fund manager, thereby limiting the benefit of external service providers that value individual investment positions and/or determine and report the fund's official NAV (for a discussion, see McVea 2008a).

Finally, the role of pricing controls can be limited because investment style explains a significant amount of observed serial correlation in hedge fund returns (Getmansky, Lo, and Makarov 2004). Regardless of the pricing controls in place, the characteristics of the fund's investments may drive the explanatory component of observed smoothing, and non-asset 
illiquidity explanations may be of secondary importance. Therefore, the extent that pricing controls reduce intentional smoothing is an empirical question.

\section{Sample and Empirical Measures}

\subsection{Sample}

We use both proprietary and commercial data sources to investigate hedge fund pricing controls and reported returns. We start with a database of 427 due diligence reports prepared by HedgeFundDueDiligence.com (HFDD). HFDD prepared the reports over the period 20032007. Investors commissioned these reports to assist them in evaluating whether to invest in the funds. HFDD specializes exclusively in hedge fund due diligence and obtains the information contained in these reports from several sources, including on-site visits and interviews with key staff, discussions with service providers, review of offering memorandums, examinations of public filings and registrations, verifications of key staff backgrounds, and auditor and accounting reviews. Consequently, the HFDD database overcomes potential concerns related to commercial databases that are based on self-reported fund and manager characteristics. The HFDD reports provide an extensive array of detail regarding fund and manager characteristics, portfolio characteristics, pricing controls, and contract terms.

Next, we merge these funds with monthly returns reported on at least one of the three major commercial databases: Lipper-TASS, Hedge Fund Research, and CISDM. ${ }^{1}$ Lipper TASS is commonly used for empirical investigations of hedge fund returns (for a detailed description,

\footnotetext{
${ }^{1}$ To ensure exemption from federal regulation, hedge funds are prohibited from any form of general solicitation or advertising of their services to the general public (ABA 2005 pages 214-5; Lhabitant 2008). Hence, commercial databases are a primary method that funds use to market themselves to potential investors.
} 
see Lo, 2008). Hedge Fund Research and CISDM are also used in academic research but to a lesser extent (for discussion of the Hedge Fund Research and CISDM databases and their overlaps in fund coverage with Lipper TASS, see Agarwal et al. 2009). When funds report to multiple databases, we obtain returns first from the Lipper-TASS database, then Hedge Fund Research, and finally CISDM. After we require at least 12 months of returns and that the smoothing measures converge, our sample consists of 260 funds. ${ }^{2}$ The distribution of fund returns by commercial database is as follows: Lipper-TASS, 158 funds; Hedge Fund Research, 72 funds; and CISDM, 30 funds. ${ }^{3}$ The returns cover the period starting in July 1990 and ending in January 2009 with the mean fund having 66 months of self-reported returns.

\subsection{Investment Style and Portfolio Characteristics}

Asset illiquidity varies with investment style. For example, funds that invest in convertible arbitrage typically hold less liquid assets than funds that follow an equity-based long/short strategy. Therefore, we create indicator variables for the major hedge fund investment styles to control for the mean illiquidity of each investment style. Because style designations vary across the three commercial databases, we create a series of combined classifications based on ten investment styles, namely: Convertible Arbitrage, Emerging Markets, Equity Market Neutral, Event Driven, Fixed Income, Macro, Long/Short Equity, Multi-

\footnotetext{
2 The smoothing measures do not converge for 10 funds that have at least 12 months of returns.

${ }^{3}$ To investigate the robustness of our findings to our sample requirement of at least 12 months of returns, we repeat the analysis for the 259 funds with at least 18 months of returns and for the 256 funds with at least 24 months of returns. The results using these alternative sample criteria are quantitatively similar, suggesting our findings are not driven by the sample criteria.
} 
Strategy, Fund of Funds, and Miscellaneous. ${ }^{4}$ Appendix A reconciles our classifications with those of the commercial databases. ${ }^{5}$

Table 1 Panel A provides descriptive detail on the funds' investment styles and portfolio characteristics. With respect to investment style, the most prevalent type in our sample is Long/Short Equity (29 percent). The remaining styles range from Equity Market Neutral (3 percent) to Event Driven (15 percent). Compared with the sample of hedge funds used in Getmansky, Lo, and Makarov (2004), our distribution of investment styles is similar except that it is more weighted toward Long/Short Equity (18 percent in their sample).

With respect to the liquidity of the investment positions in the hedge funds' portfolios, HFDD examines the portfolios to determine the typical number of investment positions held at any one time and the typical duration that a fund holds an investment position. We find substantial variation in the number of investment positions typically held in the funds' portfolios with 42 percent holding fewer than 40 positions, and three percent holding 1,000 or more positions. We also find variation in our sample funds' typical holding periods for the investments, with 10 percent of the funds holding investment positions for only days, and 35 percent holding their investment positions for more than a year.

\subsection{Pricing Controls}

Table 1 Panel B reports the descriptive statistics for the least objective pricing controls implemented by our sample funds. ${ }^{6}$ We find substantial variation in the source of prices used to

\footnotetext{
${ }^{4}$ Although the classifications Equity Market Neutral and Long/Short Equity appear similar, the TASS and CISDM databases classify them separately.

${ }^{5}$ Several of the funds classified by CISDM as Multi Strategy also report returns to Lipper-TASS and HFR. For those funds, Lipper-TASS and Hedge Fund Research consistently classify these funds as Fund of Funds. We therefore include the CISDM Multi Strategy style in our Fund of Funds classification.
} 
value funds' investment positions. Exchange quotes are used by 31 percent of the funds, overthe-counter (OTC) quotes are used by five percent of the funds, and dealer quotes are used by 36 percent. Regarding internal valuation sources, we find 12 percent of our sample funds use model-based prices; while in 15 percent, fund managers generate prices internally with no external oversight.

With respect to who prices the portfolio, we observe that nine percent of funds use at least one internal source and one external service to price investment positions (Dual/Triple Entity), while 60 percent use only external services to price the portfolio (Administrator Only). ${ }^{7}$ We also find that 12 percent of funds use collaborative pricing (Collaborative), whereby an external pricing service collaborates with the fund manager to determine the value of the fund's individual investment positions. Finally, 20 percent of the funds in the sample obtain prices internally with no external oversight (Manager Only).

With respect to who sets and reports the funds' NAV to investors, the majority of funds (84 percent) have no manager involvement in the determination and reporting of the NAV. To represent the quality and reputation of the service providers employed by our funds, we use annual hedge fund industry-specific rankings of audit firms and administrators. We obtain these rankings from Institutional Investor's Alpha Survey, which is based on voting by industry participants. All funds in the sample are audited, but there is heterogeneity in auditor quality and reputation. We use industry-specific rankings because hedge fund auditing may require specialized skills that differ from those required to audit publicly traded firms. We find that 78

\footnotetext{
${ }^{6}$ We use the least objective source to best capture the discretion that fund managers have when obtaining asset values.

${ }^{7}$ HFDD ranks Dual/Triple Entity pricing as the most stringent control over who prices investment positions.
} 
percent of our funds employ auditors ranked by Alpha Magazine, while 32 percent of our funds employ ranked administrators.

\subsection{Pricing Controls Classified by Style and Portfolio Characteristics}

Table 2 reports the pricing controls tabulated by the funds' investment styles and the liquidity of their investments. We observe substantial variation in pricing controls across funds with similar investment styles and portfolio characteristics. These differences are consistent with practitioner surveys and prior research that finds wide variation in the pricing controls used by hedge funds even within similar investment characteristics (Deloitte 2007; McVea 2008a). Nevertheless, pricing controls vary with investment style and portfolio characteristics. For example, 92 percent of the Convertible Arbitrage funds in our sample obtain prices primarily from dealers, while 88 percent of Equity Market Neutral funds use Exchange-based prices. Therefore, we control for investment style and portfolio characteristics in our multivariate tests. Moreover, in robustness tests, we partition the sample on fund investment characteristics. The extent to which pricing controls are predetermined by a fund's characteristics will reduce the likelihood of observing significant differences in smoothed reported performance attributable to pricing controls.

\subsection{Smoothing Measures}

In this sub-section, we discuss the three measures used to investigate smoothing of returns. Hedge fund returns exhibit greater serial correlation than returns on other investment securities and portfolios (for a discussion, see Lo 2008). Getmansky, Lo, and Makarov (2004) investigate several potential reasons for the high serial correlations and conclude that the two 
most likely reasons are asset illiquidity and managerial manipulation. Therefore, our first smoothing measure is the monthly serial correlation in reported returns $\hat{\rho}_{1}$ (Serial Correlation).

To investigate the potential sources of serial correlation in reported returns, Getmansky, Lo, and Makarov (2004) assume that hedge funds do not report true economic returns. Instead, funds report a monthly observed return $R_{t}^{O}$ that is a weighted average of the fund's true economic returns $R_{t}$ over the most recent $k+1$ months:

$$
\begin{gathered}
R_{t}^{O}=\theta_{0} R_{t}+\theta_{1} R_{t-1}+\cdots+\theta_{k} R_{t-k} \\
1=\theta_{0}+\theta_{1}+\cdots+\theta_{k}
\end{gathered}
$$

This process is consistent with either managers estimating holding period returns on illiquid assets and/or manipulating reported returns. Under this process serial correlation in observed returns depends on the $\theta_{k}$ 's:

$$
\operatorname{Corr}\left(R_{t}^{O}, R_{t-m}^{O}\right)=\frac{\operatorname{Cov}\left(R_{t}^{O}, R_{t-m}^{O}\right)}{\operatorname{Var}\left(R_{t}^{O}\right)}=\frac{\sum_{j=0}^{k-m} \theta_{j} \theta_{j+m}}{\sum_{j=0}^{k} \theta_{j}^{2}} \text { if } 0 \leq m \leq k
$$

Note that the process does not affect expected returns. It does, however, lead to observed volatilities that are lower than actual volatilities and observed Sharpe Ratios that are greater than actual Sharpe Ratios: ${ }^{8}$

$$
\begin{gathered}
\operatorname{Var}\left(R_{t}^{O}\right)=\left(\theta_{0}^{2}+\theta_{1}^{2}+\cdots+\theta_{k}^{2}\right) \sigma^{2}<=\sigma^{2} \\
S R^{O} \equiv \frac{1}{\sqrt{\theta_{0}^{2}+\theta_{1}^{2}+\cdots+\theta_{k}^{2}}} \frac{E\left[R_{t}\right]}{\sqrt{\operatorname{Var}\left(R_{t}\right)}} \geq \frac{E\left[R_{t}\right]}{\sqrt{\operatorname{Var}\left(R_{t}\right)}} \equiv S R
\end{gathered}
$$


Therefore, managers who follow such a smoothing process can improve their fund's observed risk adjusted performance, which has been shown by Fung et al. (2008) to be a major determinant of capital flows. This process is, however, also consistent with the pricing of illiquid assets (Kadlec and Patterson 1999; Fisher, Gatzlaff, Geltner, and Haurin 2003). For example, non-synchronous trading of assets can introduce serial correlation into returns (Scholes and Williams 1977; Dimson 1979). Moreover, Getmansky, Lo, and Makarov (2004) find that serial correlation in hedge fund reported monthly returns varies by the liquidity of the fund's investment style.

To estimate the coefficients of the smoothing process, we follow Getmansky, Lo, and Makarov (2004) by using Maximum Likelihood to estimate a Moving Average model with two lags. Specifically, they define the demeaned return process as:

$$
X_{t}=R_{t}^{O}-\mu
$$

They then assume that actual monthly performance innovations are normally distributed, leading to the following properties:

$$
\begin{gathered}
X_{t}=\theta_{0} \eta_{t}+\theta_{1} \eta_{t-1}+\theta_{2} \eta_{t-2} \\
1=\theta_{0}+\theta_{1}+\theta_{2} \\
\eta_{k} \sim \operatorname{Nor}\left(0, \sigma_{\eta}^{2}\right)
\end{gathered}
$$

We then transform the estimated coefficients by dividing each $\hat{\theta}_{i}$ by $1+\hat{\theta}_{1}+\hat{\theta}_{2}$ to normalize them. Our second empirical smoothing measure is the first coefficient $\hat{\theta}_{0}$ (Theta

\footnotetext{
${ }^{8}$ Spurgin (2001) and Weisman (2002) describe hedge fund trading strategies that smooth returns with the express purpose of decreasing a fund's observed volatility and increasing its Sharpe Ratio. Such strategies may affect both expected returns and volatility.
} 
Coefficient) from the above estimation. The economic interpretation of this coefficient is the percentage of the month's actual performance innovation that is included in the month's reported return.

As a summary statistic for the smoothing process, Getmansky, Lo, and Makarov (2004) suggest using a Herfindahl Index to measure the concentration of the $\theta_{k}$ weights:

$$
\xi=\sum_{j=0}^{k} \theta_{j}^{2}
$$

We use $\hat{\xi}$ estimated with two lags as our third empirical measure of smoothing and refer to it further as the Smoothing Index. Lower values of $\xi$ represent greater smoothing.

Appendix B presents an example of how such a MA(2) smoothing process decreases the fund's observed standard deviation, and increases the serial correlation and risk adjusted performance of the fund. The example uses 100 simulated monthly hedge fund returns generated from a Normal Distribution with a mean of one percent and a standard deviation of 2.5 percent. The simulated monthly returns are then smoothed according to the following MA(2) process:

$$
r e t_{t}^{\text {Smooth }}=0.7 r e t_{t}+0.2 r e t_{t-1}+0.1 r e t_{t-2}
$$

This smoothing process corresponds to a $\theta_{0}$ of 0.70 and a $\xi$ of 0.54 , which are similar to Lo's (2007) estimates for convertible arbitrage funds. Although the mean return for the smoothed series is only slightly higher than the unsmoothed mean ( 0.866 percent compared to 0.864 percent), the smoothing process decreases the observed standard deviation by 27 percent (from 2.234 to 1.634 ) and increases the Sharpe Ratio by 36 percent (from 0.387 to 0.526 ), implying an economically significant increase in observed risk-adjusted performance. Furthermore, the first 
order serial correlation increases from -0.049 to 0.262 and becomes significantly different from zero at the 0.01 level.

Table 3 presents summary statistics for the three smoothing measures applied to our sample's fund returns. We winsorize all three measures to the 0.5 and 99.5 percentiles to remove the effects of outliers. The mean serial correlation for our sample funds is 0.250 and its standard deviation is 0.300 . For comparison, the serial correlation in monthly returns for the S\&P 500 Index over the same period is $-0.005 .{ }^{9}$ The mean Theta Coefficient for the funds in the sample is 0.767, implying that, on average, approximately three quarters of each month's observed return represents an innovation to fund performance. The mean Smoothing Index is 0.694 , and the standard deviation of this measure is 0.301 .

Panel B presents the Pearson correlations among the three measures. Although there are differences in the number of months covered by the three measures, all three are highly correlated. For example, the correlation between Serial Correlation and Theta Coefficient is 0.838, and the correlation between Theta Coefficient and Smoothing Index is 0.960. In the empirical analyses, we use all three measures because of differences in the number of months' returns that the measures take into account.

\section{Empirical Tests}

\footnotetext{
${ }^{9}$ A potential explanation for serial correlation in hedge fund returns is that funds pursue momentum strategies. To investigate this possibility, we estimated the monthly serial correlation in the momentum factors over the period starting January 1978 and ending September 2008. The monthly serial correlation over this period is -0.017 and is not significantly different from zero. We obtain the momentum factor from Ken French's website: http://mba.tuck.dartmouth.edu/pages/faculty/ken.french/data library.html.
} 
Consistent with prior research on hedge funds, to identify the effect of pricing controls, we assume that the fund's investment style is constant over the period for which we have selfreported returns. This assumption is reasonable given that fund managers typically start a new fund rather than change the investment style of an existing fund (for a discussion see Agarwal et al. 2009). With respect to pricing controls, we assume that they are constant over the sample period because they are typically defined in the fund's PPM and consequently require investor approval to change (Ackermann, McEnally, and Ravenscraft 1999; Cassar and Gerakos 2009).

\subsection{Univariate Findings}

Table 4 compares the means of the smoothing measures across the various pricing controls. Starting with the source of prices, we find sources that involve greater managerial discretion have smoother returns than those with less discretion. For example, the returns of funds in which the manager sets prices have a mean Serial Correlation of 0.326 , while the returns of funds in which prices are exchanged-based have a mean Serial Correlation of 0.139. The means for these two pricing sources are significantly different at the 0.01 level for all three of our smoothing measures. Furthermore, we observe for all three smoothing measures the same ordering in smoothing magnitudes, from most to least: Manager Provided, Dealer Quotes, Model Based, OTC Quotes, and Exchange Quotes. The higher levels of smoothing for ManagerProvided and Dealer Quotes are consistent with managers using discretion when personally pricing assets and with managers "dealer shopping" quotes to smooth reported performance.

When we tabulate the smoothing measures by who prices the fund's investment positions, we find a similar pattern. Pricing controls that provide managers with greater discretion are associated with smoother returns than those that allow managers less discretion 
or involve greater external oversight. For example, funds in which the manager prices investment positions with no external oversight have a mean Smoothing Index (Theta Coefficient) of -0.632 (0.732), while the mean Smoothing Index (Theta Coefficient) for funds that use Dual/Triple Entity Pricing is -0.825 (0.843). The means for these two alternative pricing controls for all three smoothing measures are significantly different at the 0.05 level.

Finally, we compare the means of the smoothing measures conditional on whether the fund uses a reputable auditor or administrator, and whether the manager is involved in setting and reporting the fund's NAV to investors. Means across these traditional internal controls are not significantly different at the 0.10 level.

\subsection{Multivariate Findings}

Table 5 presents benchmark ordinary least squares regressions modeling our three smoothing measures: Serial Correlation, Theta Coefficient, and Smoothing Index. ${ }^{10}$ These regressions include control variables that proxy for investment style and portfolio characteristics. Specifically, we include indicator variables for the investment styles and indicator variables for the typical number of investment positions, the typical investment durations, and whether the fund is located offshore.

The coefficients on our investment style measures for the Theta Coefficient and Smoothing Index are similar to those presented by Getmansky, Lo, and Makarov (2004). Consistent with their results, we find negative and significant coefficients on the following

\footnotetext{
${ }^{10}$ We estimate the smoothing measures separately from the cross-sectional regressions. An alternative approach would be to estimate them jointly using the Generalized Method of Moments. Note, however, that the median number of months used to estimate fund-level serial correlation is 72, implying a standard error of 0.014 (Brockwell and Davis 1991), which is smaller than nearly all of the standard errors of the coefficients presented in the Column 1
} 
investment styles: Convertible Arbitrage, Emerging Markets, Event Driven, and Fund of Funds. Furthermore, the overall explanatory power of our models is consistent with previous empirical evidence (Getmansky, Lo, and Makarov 2004; Lo 2008). For example, our models without pricing controls explain 24.3 percent of the variation in Serial Correlation, 14.6 percent of the variation in the Smoothing Index, and 18.1 percent of the variation in Theta Coefficient.

Table 6 Panels A, B, and C present regressions modeling our three smoothing measures as a function of the fund's pricing controls. In the presented models, we exclude the pricing control that we posit provides the least discretion for fund managers to manipulate reported performance. Therefore, the coefficient on each pricing control represents additional smoothing relative to the most stringent pricing control. The right-most columns present the full model, which includes all of the control variables and pricing controls. We report the series of models to demonstrate how the inclusion/exclusion of the various pricing controls influences the explanatory power of the overall model and that of the controls variables. We discuss our findings from Panels A, B, and C jointly below by each of the pricing controls investigated.

Examining the full model for Panel A, we find that the source of prices is significantly associated with Serial Correlation, with the returns of funds using manager-based sources having serial correlations 0.142 higher than the returns of funds that use exchange-based sources. We observe similar findings for our Theta Coefficient and Smoothing Index-managerbased sources exhibiting significantly greater manipulation in reported returns compared to exchange-based sources at the 0.01 level. Consistent with exchange-based sources being the

of Table 5. Given the magnitude of the standard errors, the benefit of using GMM to estimate both the smoothing measure and the cross-sectional regressions is marginal. 
most objective or stringent pricing source, the returns of funds that use model, dealer, and OTC sources all have significantly higher levels of smoothing than the returns of funds that use exchange-based sources.

For all three measures, we observe that returns of funds that use manager-based sources have the highest level of smoothing. For example, from the Theta Coefficient results presented in Panel B, the mean monthly self-reported return of a fund using manager-based sources represents 17.9 percent less of the month's actual performance innovation than the mean selfreported return of a fund that uses exchange-based sources $(\mathrm{p}<0.01), 12.0$ percent less than a fund that uses OTC sources ( $p<0.12)$, 8.6 percent less than model-based sources $(p<0.08)$, and 6.0 percent less than dealer-based sources $(\mathrm{p}<0.12)$. Examining all three measures, in two cases, the ordering of smoothing from most to least is manager, dealer, model, OTC, and exchange. These findings are consistent with fund managers using discretion to smooth their funds' reported performance. Furthermore, the multivariate and univariate results are consistent with managers dealer-shopping quotes to smooth reported performance.

We next examine who prices the fund's investment positions and find evidence consistent with greater discretion resulting in smoother returns. The highest level of smoothing is for funds in which the manager prices investment positions with no external oversight. The economic magnitude of who sets the prices is, however, smaller than that for the pricing sources, with only two of the smoothing measures being significantly different between funds in which the manager sets prices with no external oversight and funds that use Dual/Triple pricing. Nevertheless, the results across the three smoothing measures are consistent with 
observed smoothing increasing monotonically in the manager's involvement in the pricing of investment positions.

Consistent with the univariate evidence, we do not find lower levels of smoothing in the returns of funds that use more reputable service providers and that the exclude the manager from setting and reporting NAV. These findings suggest that the managerial involvement in the reporting of the NAV to the fund investors, and the relative reputation of those who calculate and review the reported fund investments and performance, play a smaller role in the reduction of hedge fund smoothing than pricing controls related to the source and who prices the fund's individual investments. Our results with respect to auditors, administrators, and NAV do not, however, preclude the possibility these controls affect other outcomes, such as the quality of the fund's annual financial statements or the likelihood of fraud.

Examining the relative contribution of our various pricing controls on the additional explanatory power gained suggests that the source of prices is the most influential in explaining cross-sectional variation in the smoothness of self-reported hedge fund returns. With respect to asset illiquidity vs. misreporting, the inclusion of pricing controls increases the overall explanatory power of the models by 4.1 percent (Serial Correlation), 8.1 percent (Theta Coefficient), and 7.3 percent (Smoothing Index). ${ }^{11}$ Nevertheless, the investment style and portfolio characteristics explain between 14 and 24 percent of the variation in the smoothing measures, suggesting that asset illiquidity is the major factor that drives the anomalous properties of self-reported hedge fund returns.

\footnotetext{
${ }^{11}$ Note that the $\mathrm{R}^{2}$ for Serial Correlation, Smoothing Index and Theta Coefficient with only the pricing controls are 17.3 percent, 15.2 percent, and 16.9 percent. Therefore, the inclusion of the control variables increases the overall explanatory power of the models by 11.1 percent, 7.5 percent, and 8.5 percent.
} 


\section{Robustness Tests}

\subsection{Within Typical Holding Period and Typical Number of Positions}

The results presented in Tables 5 and 6 also include indicator variables for the typical periods that funds hold investment positions and the typical number of positions, thereby controlling for these effects. An alternative approach is to examine the associations among the pricing controls and smoothing measures within each typical holding period and within each typical number of positions. An advantage of this approach is that it may better hold the liquidity of the fund's portfolio constant. In unreported tests, we carry out such analyses for sub-samples based on typical number of positions and typical holding period. Consistent with the reported results, we find significantly higher levels of smoothing at the 0.10 level for funds in which the manager is involved in pricing and in which prices are sourced from dealers for all numbers of positions and for durations of a year, quarter, and month.

\subsection{Within Investment Style}

The results presented in Tables 5 and 6 include indicator variables for the various investment styles, several of which are statistically significant. Therefore, the results represent associations between pricing controls and smoothing when investment style is held constant. An alternative approach is to examine the associations among the pricing controls and smoothing measures within the investment style. Several of the styles include only a small number of funds, and pricing controls cluster within these styles. Nevertheless, we examine the association between pricing controls and the smoothness measures for Event Driven funds, which is the largest investment style (38 funds) in our sample. 
Table 7 presents the means of the smoothing measures classified by the source of prices and by who prices the investment positions. OTC Quotes is excluded from the analysis because no Event Driven fund in the sample uses OTC Quotes as a source of prices. Consistent with the results presented in Table 6, within the Event Driven style we find the smoothest returns among funds in which managers provide prices and funds in which managers price investment positions with no external oversight. In addition, Dealer Quotes are associated with the next highest level of smoothing.

\subsection{Manager Skill}

A hedge fund investment is effectively a bet on the fund manager's proprietary investment strategies and/or investing skill (Edwards and Caglayan 2001; Lo 2008). If a fund manager has greater investment ability, both the manager and the investors are likely to have incentives to mask the fund's investment strategy to other investors. One method to reduce the likelihood of outsiders being able to ascertain the fund's investment strategy from reported returns is to allow better managers to smooth returns. But, managers choose whether to selfreport returns to commercial databases and higher-ability managers may therefore not report. Nevertheless, in this section we examine whether the pricing controls are associated with manager skill.

To investigate this issue we first estimate a measure of fund manager skill, namely the alphas estimated over the life of the fund. To calculate fund level alphas, we regress each fund's monthly returns on Fung and Hsieh's (2001) eight hedge fund risk factors (the returns of S\&P 500, the small capitalization minus large capitalization factor, the bond trend following factor, the currency trend following factor, the commodity trend following factor, the stock index trend 
following factor, the bond market factor, and the credit spread factor). ${ }^{12}$ The intercept from each fund level regression represents the fund's alpha.

Table 8 tabulates the means for sample funds' alphas by the various pricing controls. We observe no obvious association between discretion in reporting, as represented by weaker pricing controls. For example, the mean alpha for funds in which the manager provides prices is significantly lower than that for funds that use Exchange-based prices. And, the alphas for funds in which the manager prices investment positions with no external oversight are not significantly different from the alphas for funds that use Dual/Triple Entity pricing.

Furthermore, we find similar results when we control for the funds' investment styles and portfolio characteristics. These analyses suggest that manager skill is not a correlated omitted variable.

\subsection{Regulatory Jurisdiction}

Cumming (2008) finds that variation in hedge fund regulation is associated with the probability that reported returns are marginally positive, as opposed to zero or negative. He argues that greater regulatory oversight provides additional value-added governance, eliminates lower-quality funds, and enables engagement in surveillance. Rather than use an indirect measure of hedge fund manager reporting discretion based on jurisdiction, we directly observe the pricing controls employed by funds, and find variation in pricing mechanisms conditional on the funds' domiciles. For example, Cassar and Gerakos (2009) report variation in several internal control choices, including pricing controls, both across and within the fund domiciles in our sample. Nevertheless, we examine the robustness of our findings by including

\footnotetext{
${ }_{12}$ We obtained the factors from David Hsieh's website: http://faculty.fuqua.duke.edu/ dah/DataLibrary/TF-FAC.xls
} 
the fund domicile variables in the reported analyses with indicator variables for each country with 10 or more funds. Our results are not altered in terms of both magnitude and statistical significance of our main coefficient estimates by the inclusion of country dummies.

\subsection{Before and After Due Diligence}

We assume that the relation between pricing controls and the smoothing measures is constant over the reporting history of the fund. To investigate this assumption, we repeat the analyses presented in Table 4 using smoothing measures estimated using returns reported before and after the due diligence reports. One issue arises from examining only returns that were reported either before or after the due diligence report-the sample size drops to 161 funds before the due diligence report and to 222 funds for after. ${ }^{13}$

Table 9 Panels A and B presents ordinary least squares regressions in which the smoothing measures are estimated using returns that reported either before or after the due diligence report was completed. In these regressions, we include the variables for who prices and the source of prices. The results are qualitatively similar to those presented in Table 6 except for the following point. As presented in Panel A, for returns reported before the due diligence report, we find no differences between the smoothing measures estimated before due diligence for who prices the investment positions. An explanation for this result is the smaller sample size and potential differences between established funds and newly established funds that would not be included in the tests based on returns reported prior to the due diligence report.

\footnotetext{
${ }^{13}$ The before and after sample sizes are not equivalent because we require a minimum of 12 months of returns, and some funds initiated or terminated reporting to the commercial databases within 12 months before or after the due diligence report was completed.
} 


\subsection{Alternative Measure of Pricing Sources}

In the presented analyses, we employ the least objective pricing source used by the fund to value its investment positions. We use the least objective source to capture the discretion that fund managers have when obtaining asset values. But, many hedge funds use multiple sources to obtain prices (Deloitte 2007 page 15; HFWG 2007 page 18; President's Working Group 2008 page 46). We therefore repeat the analyses using every pricing source that the fund employs. We find that the results obtained using this alternative measure are similar to those presented and are consequently not reported.

\section{Distribution Tests}

In this section, we examine whether the likelihood of reporting a small positive versus a small negative return varies with the source of prices. This approach allows us to further validate our identification of the effect of pricing controls on reported returns because the liquidity of the fund's investment is not likely to affect the likelihood of small positive vs. small negative returns.

Bollen and Pool (2009) find a significant discontinuity around zero in the pooled distribution of monthly hedge fund returns, with the number of small gains far exceeding the number of small negative returns. ${ }^{14}$ Further, they observe that there is no discontinuity in the three months culminating in an audit, and that the presence of the discontinuity varies by some fund investment styles. They posit that some managers distort returns and that this distortion is

\footnotetext{
${ }^{14}$ Burgstahler and Dichev (1997) document a similar discontinuity around zero in corporate earnings.
} 
more likely when managers have greater discretion due to the liquidity of their invested assets and when managers are not closely monitored.

Figure 1 presents histograms of reported returns for the full sample and for each pricing source. To determine bin size and statistical significance, we follow Bollen and Pool (2009) and set bin width using the Silverman's (1986) heuristic:

$$
1.364 \alpha \min (\sigma, Q / 1.340) N^{-\frac{1}{5}}
$$

in which $\sigma$ is the sample's standard deviation, $Q$ is its inter-quartile range, and $N$ is the sample size. We assume a normal distribution and therefore set $\alpha$ equal to 0.776 . With respect to statistical significance we fit a Gaussian kernel and then compare the predicted vs. actual number of observations in each bin. We determine significance using the Demoivre-Laplance theorem that states the number of observations in each bin is asymptotically normal. Consistent with Bollen and Pool (2009), Panel A shows that when we pool the returns of all funds in our sample, that small positive returns are more likely than predicted and that small negative returns less likely than predicted, with both effects statistically significant at the five percent level.

When we classify funds by the source of prices, we find results similar to those presented in Table 6. Panels D and F show that for Dealer Quotes and Manager-Provided small positive returns are more likely than predicted and that small negative returns less likely than predicted, with all effects statistically significant at the one percent level except for small positive returns for Manager Provided which is significant at the 10 percent level. In contrast, Panels B, C, and E show that for Exchange Quotes, OTC Quotes, and Model-Based small 
positive returns are statistically more likely than predicted at the five percent level, while small negative returns are not statistically different than predicted at the 10 percent level. In unreported tests, we classify funds by the typical number of positions and the typical holding period of an investment position. For these histograms, the magnitude of the jump at zero is similar for all positions and all holding periods, suggesting that asset illiquidity does not drive the discontinuities at zero.

\section{Conclusion}

We investigate the extent that hedge fund managers smooth self-reported returns. In contrast with prior research on the anomalous properties of hedge fund returns, we observe the mechanisms used to price the fund's investment positions and report the fund's performance to investors, thereby allowing us to differentiate between asset illiquidity and misreporting-based explanations. We find that funds using less verifiable pricing sources and funds that provide managers with greater discretion in pricing investment positions are more likely to have returns that are consistent with intentional smoothing. Traditional controls, however, such as removing the manager from setting and reporting the fund's net asset value and the use of reputable auditors and administrators are not associated with lower levels of smoothing. With respect to asset illiquidity vs. misreporting, investment style and portfolio characteristics explain 14.0-24.3 percent of the variation in our smoothing measures and pricing controls explain an additional 4.1-8.8 percent, suggesting that asset illiquidity is the major factor driving the anomalous properties of self-reported hedge fund returns. 
This study extends both the hedge fund and financial reporting literatures. We extend the hedge fund literature by estimating the magnitudes of intentional smoothing. These estimates have important implications for investors or researchers who use reported hedge fund returns to evaluate hedge fund investment opportunities and/or hedge funds as an asset class. The study also extends the financial reporting literature by demonstrating how pricing controls affect the "marking to market" of investment positions. Managerial discretion in "marking to market" investment positions is a controversial subject given the issues associated with recent credit crisis and the implementation of FAS 157. Our evidence demonstrates that the effectiveness of various pricing controls in constraining managerial manipulation of mark to market accounting. 


\section{References}

Ackermann, C., R. McEnally, and D. Ravenscraft. 1999. The Performance of Hedge Funds: Risk, Return, and Incentives. Journal of Finance 54:833-74.

Agarwal, V., N. Daniel, and N. Naik. 2009. Role of Managerial Incentives and Discretion in Hedge Fund Performance. Journal of Finance 64:2221-56.

Alternative Investment Management Association (AIMA), 2005. Asset Pricing and Fund Valuation Practices in the Hedge Fund Industry.

American Bar Association (ABA) 2005. U.S. Regulation of Hedge Funds.

Aragon, G. 2007. Share restrictions and asset pricing: Evidence from the hedge fund industry. Journal of Financial Economics 83:33-58.

Asness, C., R. Krail, and J. Liew. 2001. Do Hedge Funds Hedge? Journal of Portfolio Management Fall:6-19.

Bollen, N., and V. Pool. 2009. Do Hedge Fund Managers Misreport Returns? Evidence from the Pooled Distribution. Journal of Finance 64:2257-88.

Bollen, N, and V. Pool. 2008. Conditional Return Smoothing in the Hedge Fund Industry. Journal of Financial and Quantitative Analysis 43:267-98.

Boudoukh, J., M. Richardson, M. Subrahmanyam, and R. Whitelaw. 2002. Stale prices and strategies for trading mutual funds. Financial Analysts Journal 58:53-71.

Brockwell, P., and R. Davis. 1991. Time series: theory and methods. New York: Springer.

Brown, S., W. Goetzmann, and R. Ibbotson. 1999. Offshore Hedge Funds: Survival and Performance, 1989-95. Journal of Business 72:91-117.

Burgstahler, D., and I. Dichev. 1997. Earnings management to avoid earnings decreases and losses. Journal of Accounting and Economics 24:99-126.

Cassar, G., and J. Gerakos. 2009. Determinants of Hedge Fund Internal Controls and Fees. Working paper, The Wharton School.

Chandar, N., and R. Bricker. 2002. Incentives, discretion, and asset valuation in closed-end mutual funds. Journal of Accounting Research 40:1037-70.

Cumming, D. 2008. Hedge Fund Regulation and Misreported Returns. Working paper, York University. 
Dechow, P., W. Ge, and C. Schrand. 2009. Understanding Earnings Quality: A Review of the Proxies, their Determinants and their Consequences. Working paper, The Wharton School.

Deloitte. 2007. Precautions that Pay Off: Risk Management and Valuation Practices in the Global Hedge Fund Industry.

Dimson, E. 1979. Risk measurement when shares are subject to infrequent trading. Journal of Financial Economics 7:197-226.

Fisher, J., D. Gatzlaff, D. Geltner, and D. Haurin. 2003. Controlling for the Impact of Variable Liquidity in Commercial Real Estate Price Indices. Real Estate Economics 31:269-304.

Fung, W., and D. Hsieh. 1999. A Primer on Hedge Funds. Journal of Empirical Finance 6:309-31.

Fung, W., D. Hsieh, N. Naik, and T. Ramadorai. 2008. Hedge Funds: Performance, Risk, and Capital Formation. Journal of Finance 63:1777-1803.

Getmansky, M., A. Lo, and I. Makarov. 2004. An econometric model of serial correlation and illiquidity in hedge fund returns. Journal of Financial Economics 74:529-609.

Hedge Fund Working Group (HFWG). 2007. Hedge Fund Standards: Consultation Paper. Part 2: The Best Practice Standards.

Kadlec, G., and D. Patterson. 1999. A transactions data analysis of nonsynchronous trading. Review of Financial Studies 12:609-30.

Khandani, A., and A. Lo. 2009. Illiquidity Premia in Asset Returns: An Empirical Analysis of Hedge Funds, Mutual Funds, and U.S. Equity Portfolios. Working paper, MIT.

Laux, C., and C. Leuz. 2009. The crisis of fair-value accounting: Making sense of the recent debate. Accounting, Organizations and Society 34:826-34.

Lhabitant, F. 2008. Handbook of Hedge Funds. West Sussex, UK: Wiley Finance.

Lo, A. 2008. Hedge Funds: An Analytic Perspective. Princeton, NJ: Princeton University Press.

Managed Funds Association (MFA). 2009. Sound Practices for Hedge Fund Managers.

McVea, H. 2008a. Hedge fund administrators and asset valuations-does it all add up? Journal of Financial Regulation and Compliance 16:130-41.

McVea, H. 2008b. Hedge fund asset valuations and the work of the International Organization of Securities Commissions (IOSCO). International and Comparative Law Quarterly 57:1-24. 
Oesterle, D. 2008. Regulating Hedge Funds. Center for Interdisciplinary Law and Policy Studies Working Paper No. 47.

Report of the Investors Committee to the President's Working Group on Financial Markets (President's Working Group). 2008. Principles and Best Practices for Hedge Fund Investors.

Scholes, M., and J. Williams. 1977. Estimating betas from nonsynchronous data. Journal of Financial Economics 5:309-27.

Scholtes, S., and G. Tett. 2007. Worries grow about the true value of repackaged debt. Financial Times June 27.

Securities and Exchange Commission (SEC). 2003. Implications of the Growth of Hedge Funds. Staff Report.

Silverman, B. 1986. Density estimation for statistics and data analysis. New York, NY: Chapman and Hall.

Skeel, D., and F. Partnoy. 2007. The promise of perils of credit derivatives. University of Cincinnati Law Review 75:1019-51.

Spurgin, R. 2001. How to game your Sharpe ratio. The Journal of Alternative Investments 4:38-46.

Weisman, A. 2002. Informationless Investing and Hedge Fund Performance Measurement Bias. Journal of Portfolio Management 28:80-91. 


\section{Appendix A Style Classification}

\begin{tabular}{|c|c|c|}
\hline Style: & Vendor Style & Vendor: \\
\hline \multirow[t]{2}{*}{ Convertible Arbitrage } & Convertible Arbitrage & CISDM \\
\hline & Convertible Arbitrage & TASS \\
\hline \multirow[t]{2}{*}{ Emerging Markets } & Emerging Markets & CISDM \\
\hline & Emerging Markets & TASS \\
\hline \multirow[t]{3}{*}{ Equity Market Neutral } & Equity Market Neutral & CISDM \\
\hline & Market Neutral & CISDM \\
\hline & Equity Market Neutral & TASS \\
\hline \multirow[t]{6}{*}{ Event Driven } & Event Driven Multi Strategy & CISDM \\
\hline & Capital Structure Arbitrage & CISDM \\
\hline & Merger Arbitrage & CISDM \\
\hline & Option Arbitrage & CISDM \\
\hline & Event-Driven & HFR \\
\hline & Event Driven & TASS \\
\hline \multirow[t]{4}{*}{ Fixed Income Arbitrage } & Fixed Income & CISDM \\
\hline & Fixed Income - MBS & CISDM \\
\hline & Fixed Income Arbitrage & CISDM \\
\hline & Fixed Income Arbitrage & TASS \\
\hline \multirow[t]{3}{*}{ Global Macro } & Global Macro & CISDM \\
\hline & Macro & HFR \\
\hline & Global Macro & TASS \\
\hline \multirow[t]{3}{*}{ Long/Short Equity } & Equity Long/Short & CISDM \\
\hline & Equity Hedge & HFR \\
\hline & Long/Short Equity Hedge & TASS \\
\hline \multirow[t]{3}{*}{ Multi-Strategy } & Relative Value Multi Strategy & CISDM \\
\hline & Relative Value & HFR \\
\hline & Multi-Strategy & TASS \\
\hline \multirow[t]{3}{*}{ Fund of Funds } & Multi Strategy & CISDM \\
\hline & Fund of Funds & HFR \\
\hline & Fund of Funds & TASS \\
\hline \multirow[t]{8}{*}{ Miscellaneous } & Dedicated Short Bias & TASS \\
\hline & Commodity Pool Operator & CISDM \\
\hline & Managed Futures & TASS \\
\hline & Equity Long Only & CISDM \\
\hline & Regulation D & CISDM \\
\hline & Sector & CISDM \\
\hline & Single Strategy & CISDM \\
\hline & Systematic & CISDM \\
\hline
\end{tabular}




\section{Appendix B \\ Smoothing Example}

This Appendix presents an example of smoothing using a MA(2) process. Hedge fund returns for 100 months were generated from a Normal Distribution with a mean of 1 percent and a standard deviation of 2.5 percent. They were then smoothed according to the following MA(2) process:

$$
\mathrm{ret}_{t}^{\text {Smooth }}=0.7 r e t_{t}+0.2 \mathrm{ret}_{t-1}+0.1 \mathrm{ret}_{t-2}
$$

This smoothing process corresponds to a $\theta_{0}$ of 0.70 and a $\xi$ of 0.54 . The unsmoothed and smoothed return series have the following characteristics:

\begin{tabular}{lcc}
\hline \hline & Unsmoothed & Smoothed \\
\hline \hline Mean (\%) & 0.864 & 0.866 \\
Standard Deviation (\%) & 2.234 & 1.634 \\
Sharpe Ratio & 0.387 & 0.526 \\
First Order Autocorrelation & -0.049 & $0.262^{*}$ \\
\hline \hline
\end{tabular}

* Significantly different from zero at the .01 level

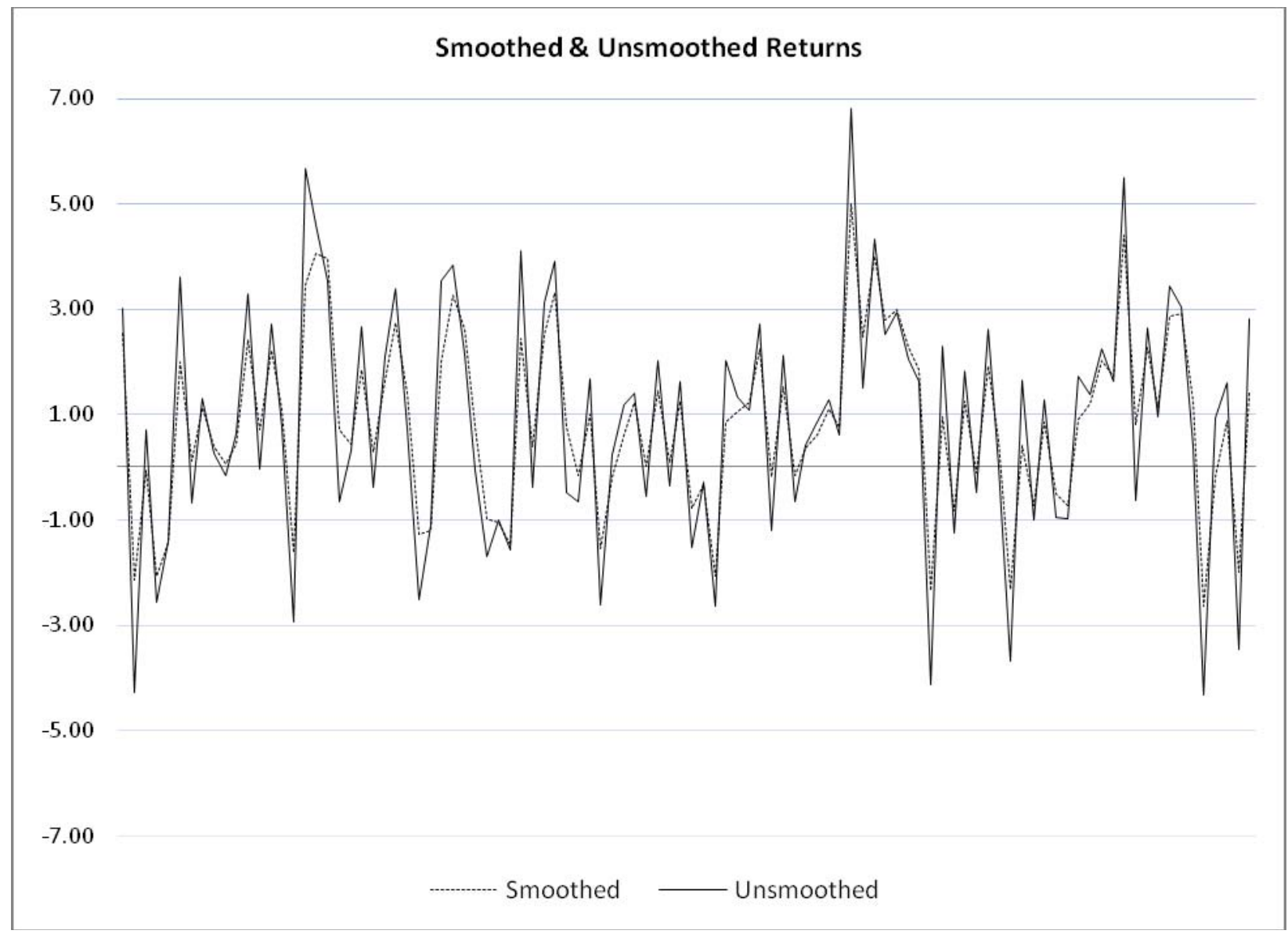




\section{Figure 1}

This Figure presents histograms of the monthly returns for the full sample (Panel A) and for each source of prices (Panels B, C, D, E, and F). bin width using the Silverman's (1986) heuristic:

$$
1.364 \alpha \min (\sigma, Q / 1.340) N^{-\frac{1}{5}}
$$

in which $\sigma$ is the sample's standard deviation, $Q$ is its inter-quartile range, and $N$ is the sample size.

Panel A: All funds

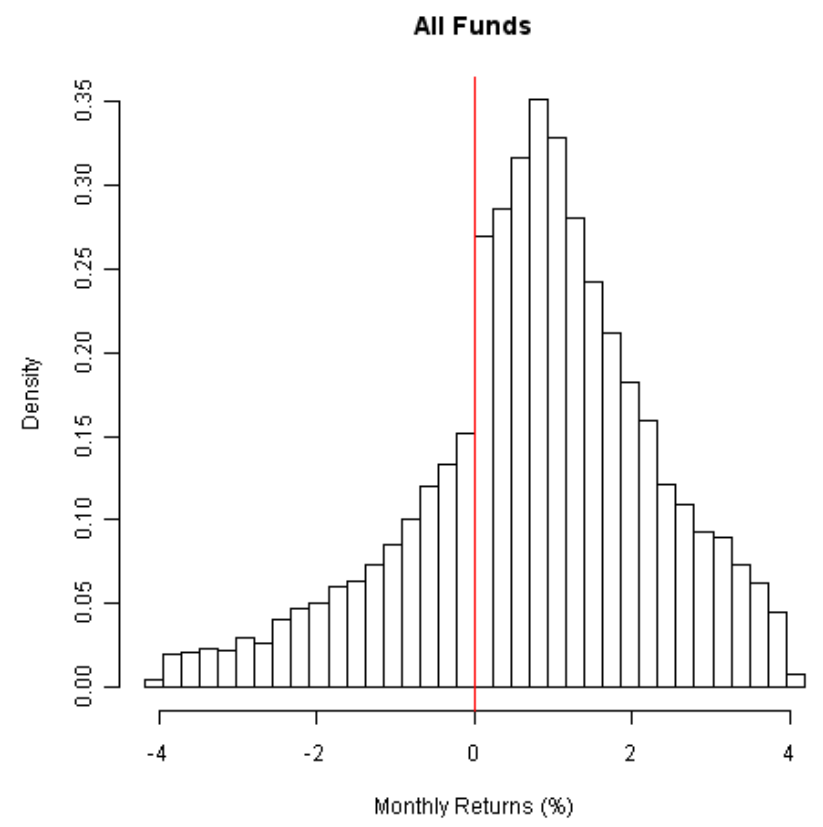

Panel B: Funds the price investment positions primarily using Exchange Quotes

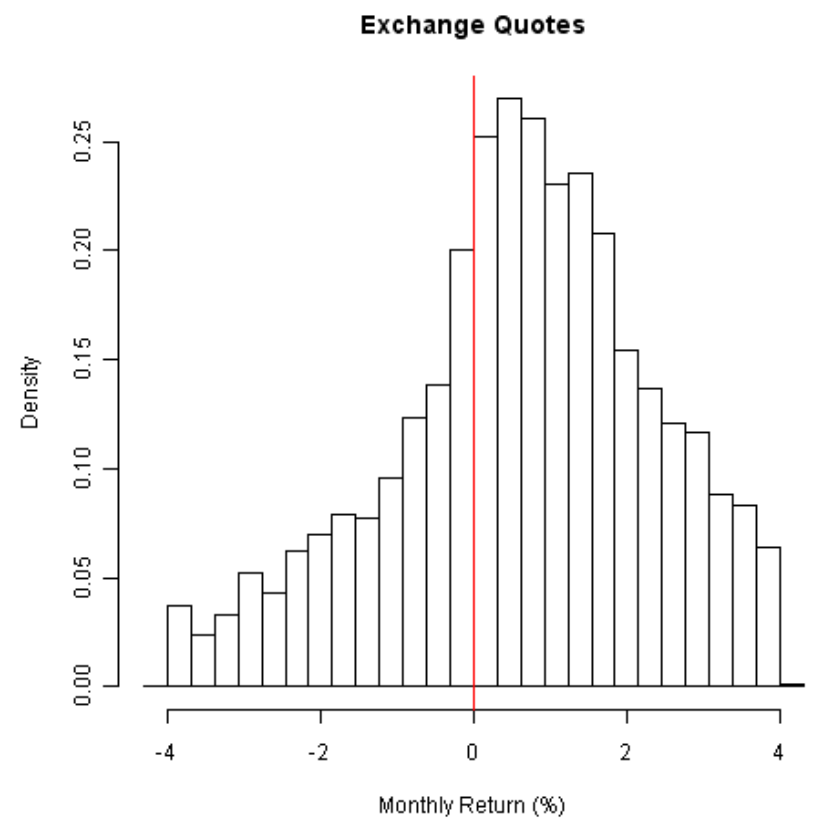


Figure 1 (contd.)

Panel C: Funds that price investment positions primarily using OTC Quotes

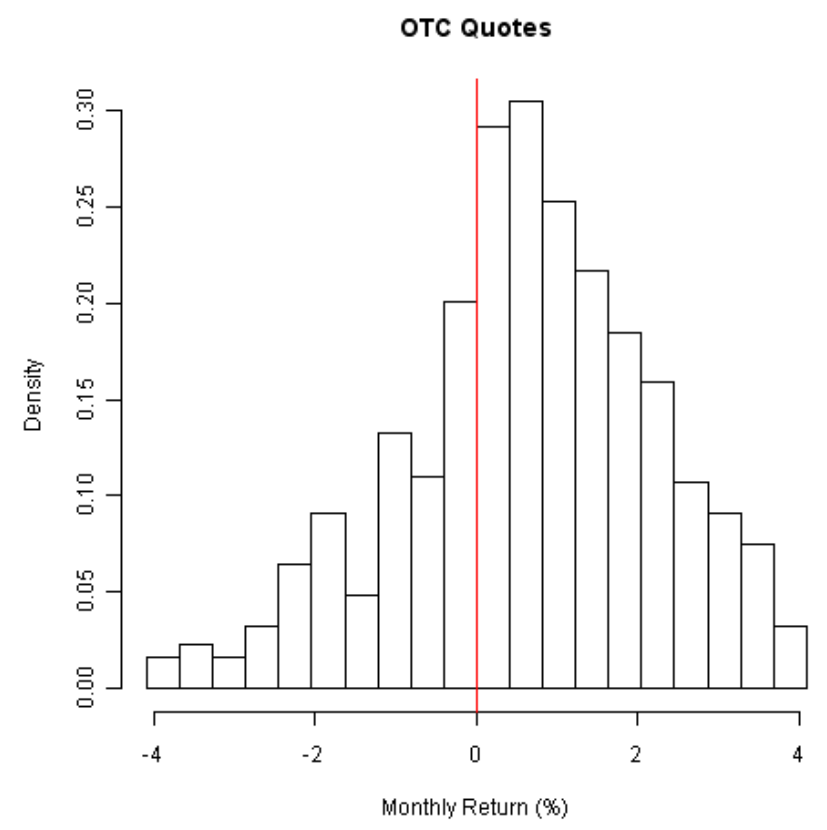

Panel D: Funds that price positions primarily using Dealer Quotes

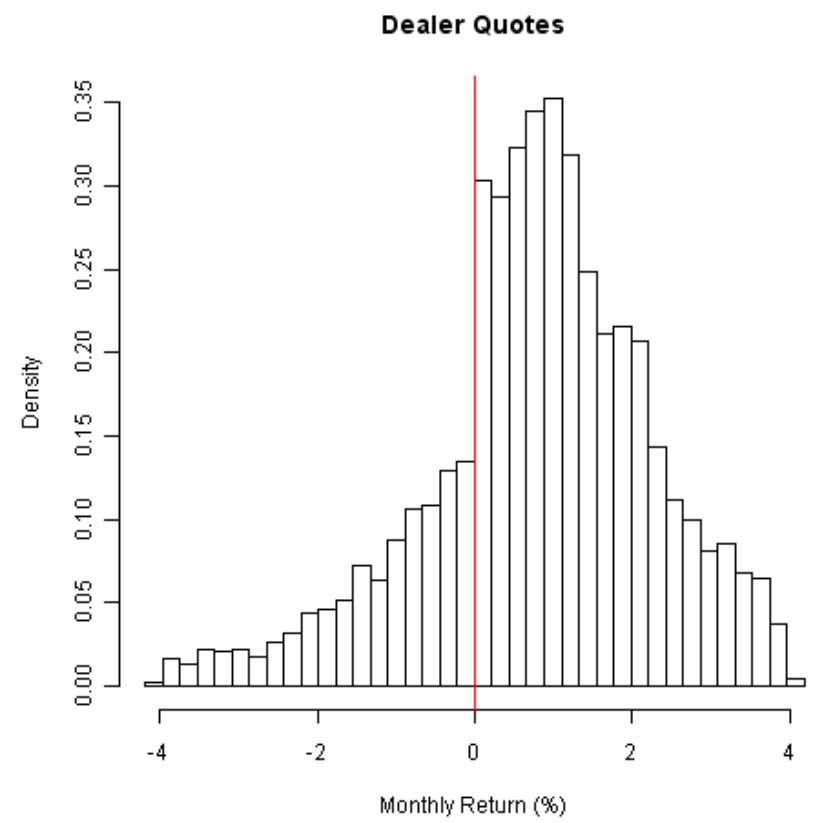




\section{Figure 1 (contd.)}

Panel E: Funds that price positions primarily using Models

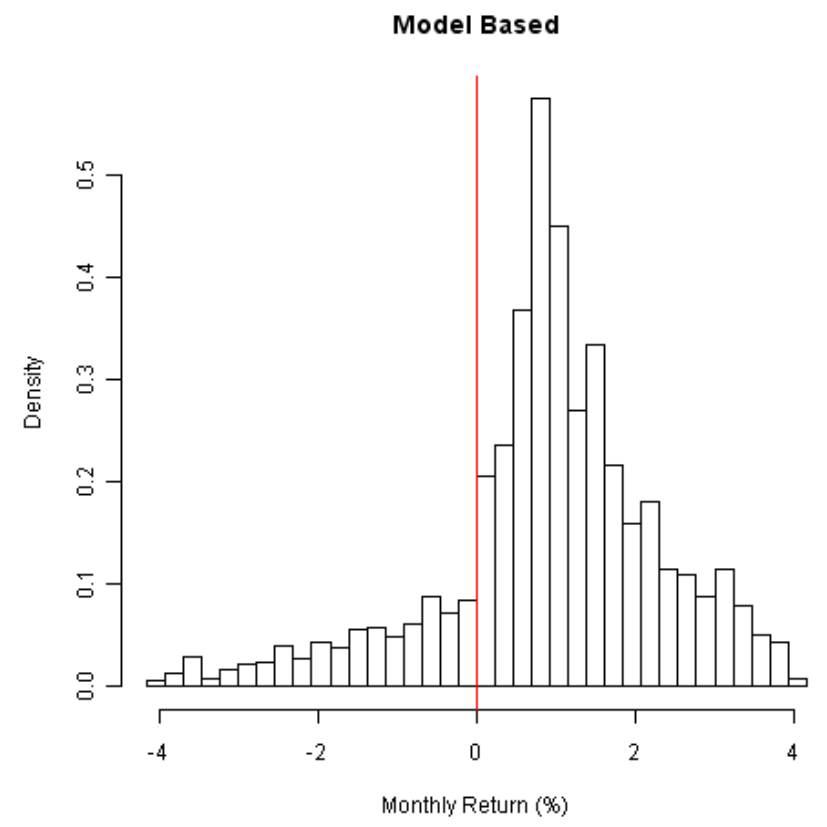

Panel F: Funds in which the manager is the primary provider of prices

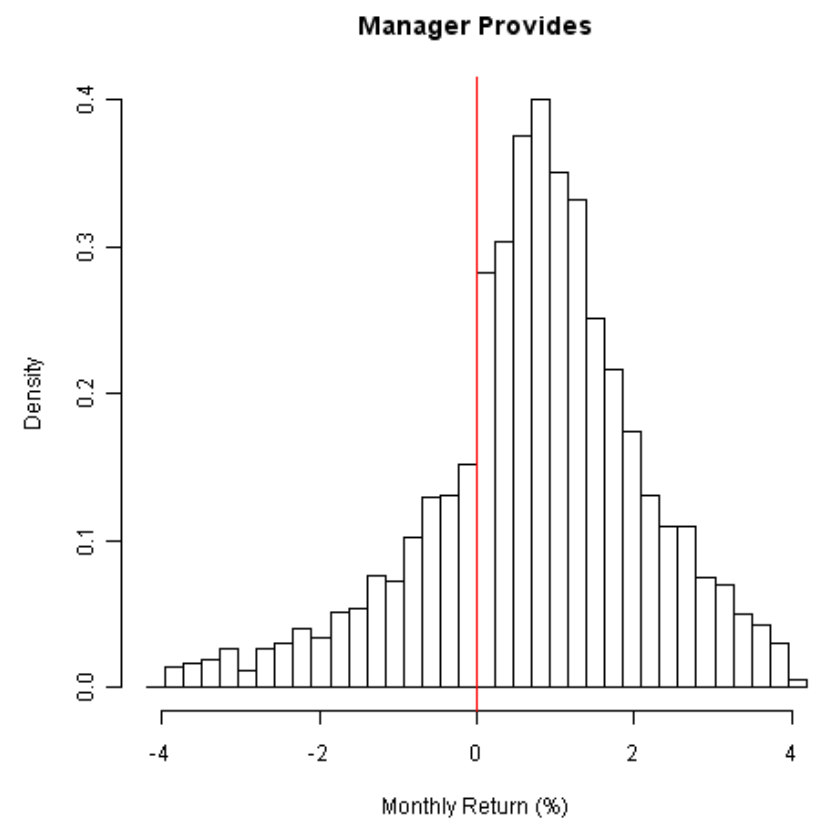




\section{Table 1}

\section{Descriptive Statistics}

This table presents summary statistics of the investment style, portfolio characteristics, and pricing control measures for the 260 hedge funds in our sample. Appendix A describes the investment style variables. 1000+ Positions, 200-999 Positions, 100-199 Positions, 40-99 Positions, and 1-39 Positions are indicator variables for the average number of positions held in the fund's portfolio. Years, Quarters, Months, Weeks, and Days are indicator variables for the average holding period of a position. Fund Offshore is and indicator variable for whether the fund is domiciled offshore. Manager Provided, Model Based, Dealer Quotes, OTC Quotes, and Exchange Quotes are indicator variables representing the primary source of prices used to value the fund's investment positions. Manager Only is an indicator variable for whether the manager prices investment positions with no outside oversight. Collaborative is an indicator variable for whether the manager and an outside administrator collaborate on the pricing of positions. Administrator Only is an indicator variable for whether only an outside administrator prices the positions. Dual/Triple Entity is an indicator variable for whether the fund uses at least one internal service and one external service to price the portfolio. NAV Manager is an indicator variable for whether the manager is involved in reporting of the net asset value to the fund's investors. Auditor Not Ranked and Administrator Not Ranked are indicator variables for whether the fund's auditor and administrator are not included Institutional Investor's Alpha Magazine annual lists of top hedge fund service providers.

Panel A:

\begin{tabular}{lr}
\hline Variable (\%) & Overall \\
\hline Investment Style: & 5 \\
Convertible Arbitrage & 5 \\
Emerging Markets & 3 \\
Equity Market Neutral & 15 \\
Event Driven & 6 \\
Fixed Income Arbitrage & 10 \\
Global Macro & 29 \\
Long/ Short Equity & 13 \\
Multi-Strategy & 11 \\
Fund of Funds & 5 \\
Miscellaneous & \\
& \\
Portfolio Characteristics: & \\
1000+ Positions & 3 \\
200-999 Positions & 5 \\
100-199 Positions & 13 \\
40-99 Positions & 38 \\
1-39 Positions & 42 \\
Years & 35 \\
Quarters & 33 \\
Months & 35 \\
Weeks & 13 \\
Days & \\
Fund Offshore & \\
\hline \hline
\end{tabular}

Panel B:

\begin{tabular}{lr}
\hline \hline Variable (\%) & Overall \\
\hline Source of Prices: & \\
Manager Provided & 16 \\
Model Based & 11 \\
Dealer Quotes & 36 \\
OTC Quotes & 5 \\
Exchange Quotes & 32 \\
& \\
Who Prices Positions: & \\
Manager Only & 20 \\
Collaborative & 12 \\
Administrator Only & 60 \\
Dual/Triple Entity & 9 \\
& \\
Other: & \\
NAV Manager & 14 \\
Auditor Not Ranked & 23 \\
Administrator Not Ranked & 68 \\
\end{tabular}


Table 2

Pricing Controls Conditional on Investment Style and Portfolio Characteristics

This table presents distributions of the pricing controls measures conditional on investment styles and portfolio characteristics. Panel A presents the conditional distributions of pricing sources. Panel B presents the conditional distributions of who prices the investment positions. Panel $\mathrm{C}$ presents the conditional distributions of NAV Manager, Auditor Not Ranked, and Administrator Not Ranked. Variable definitions are provided in the notes to Table 1.

Panel A: Source of Prices

\begin{tabular}{|c|c|c|c|c|c|}
\hline Variable (\%) & Manager & Model & Dealer & OTC & Exchange \\
\hline \multicolumn{6}{|l|}{ Investment Style: } \\
\hline Convertible Arbitrage & 0 & 8 & 92 & 0 & 0 \\
\hline Emerging Markets & 15 & 38 & 46 & 0 & 0 \\
\hline Equity Market Neutral & 0 & 0 & 0 & 13 & 88 \\
\hline Event Driven & 26 & 8 & 58 & 0 & 8 \\
\hline Fixed Income Arbitrage & 0 & 33 & 60 & 7 & 0 \\
\hline Global Macro & 0 & 0 & 32 & 28 & 40 \\
\hline Long/ Short Equity & 1 & 9 & 16 & 4 & 69 \\
\hline Multi-Strategy & 12 & 15 & 61 & 0 & 12 \\
\hline Fund of Funds & 79 & 0 & 11 & 0 & 11 \\
\hline Miscellaneous & 17 & 25 & 17 & 0 & 42 \\
\hline \multicolumn{6}{|l|}{ Portfolio Characteristics: } \\
\hline 1000+ Positions & 43 & 14 & 0 & 0 & 43 \\
\hline 200-999 Positions & 15 & 23 & 31 & 8 & 23 \\
\hline 100-199 Positions & 3 & 9 & 41 & 3 & 44 \\
\hline 40-99 Positions & 11 & 10 & 43 & 3 & 33 \\
\hline 1-39 Positions & 22 & 11 & 31 & 6 & 29 \\
\hline Years & 30 & 16 & 36 & 1 & 18 \\
\hline Quarters & 8 & 9 & 39 & 6 & 39 \\
\hline Months & 6 & 11 & 34 & 11 & 37 \\
\hline Weeks & 5 & 5 & 45 & 5 & 40 \\
\hline Days & 16 & 8 & 24 & 4 & 48 \\
\hline Fund Offshore & 14 & 11 & 40 & 5 & 31 \\
\hline
\end{tabular}


Table 2 (continued)

Pricing Controls Conditional on Investment Style and Portfolio Characteristics

Panel B: Who Prices Positions

\begin{tabular}{lcccc}
\hline Variable (\%) & Manager & Collaborative & Administrator & Dual /Triple \\
\cline { 2 - 5 } Investment Style: & & & & \\
Convertible Arbitrage & 23 & 8 & 69 & 0 \\
Emerging Markets & 38 & 8 & 54 & 0 \\
Equity Market Neutral & 13 & 0 & 87 & 0 \\
Event Driven & 21 & 32 & 29 & 18 \\
Fixed Income Arbitrage & 40 & 13 & 33 & 13 \\
Global Macro & 8 & 4 & 68 & 20 \\
Long/ Short Equity & 9 & 8 & 76 & 7 \\
Multi-Strategy & 24 & 12 & 55 & 9 \\
Fund of Funds & 21 & 0 & 75 & 4 \\
Miscellaneous & 42 & 25 & 25 & 8 \\
Portfolio Characteristics: & & & & \\
1000+ Positions & 14 & 29 & 57 & 0 \\
200-999 Positions & 31 & 8 & 54 & 8 \\
100-199 Positions & 9 & 9 & 68 & 15 \\
40-99 Positions & 19 & 10 & 64 & 6 \\
1-39 Positions & 22 & 13 & 54 & 11 \\
Years & 20 & 9 & 63 & 8 \\
Quarters & 18 & 11 & 62 & 9 \\
Months & 29 & 17 & 49 & 6 \\
Weeks & 5 & 60 & 20 \\
Days & 15 & 20 & 52 & 12 \\
Fund Offshore & 16 & 63 & 10 \\
\hline \hline
\end{tabular}


Table 2 (continued)

Pricing Controls Conditional on Investment Style and Portfolio Characteristics

Panel C: NAV No Manager, Auditor Ranked, and Administrator Ranked

\begin{tabular}{lrcc}
\hline \hline Variable (\%) & $\begin{array}{c}\text { NAV } \\
\text { Manager }\end{array}$ & $\begin{array}{c}\text { Auditor } \\
\text { Not Ranked }\end{array}$ & $\begin{array}{c}\text { Administrator } \\
\text { Not Ranked }\end{array}$ \\
\cline { 2 - 4 } $\begin{array}{l}\text { Investment Style: } \\
\text { Convertible Arbitrage }\end{array}$ & 23 & 23 & 77 \\
Emerging Markets & 8 & 8 & 69 \\
Equity Market Neutral & 12 & 25 & 62 \\
Event Driven & 24 & 21 & 66 \\
Fixed Income Arbitrage & 33 & 20 & 87 \\
Global Macro & 4 & 20 & 64 \\
Long/ Short Equity & 9 & 19 & 56 \\
Multi-Strategy & 21 & 30 & 79 \\
Fund of Funds & 18 & 25 & 75 \\
Miscellaneous & 25 & 50 & 75 \\
Portfolio Characteristics: & & & \\
1000+ Positions & & & 43 \\
200-999 Positions & 14 & 14 & 77 \\
100-199 Positions & 31 & 31 & 62 \\
40-99 Positions & 6 & 18 & 66 \\
1-39 Positions & 21 & 19 & 71 \\
Years & 13 & 27 & 68 \\
Quarters & 19 & 28 & 71 \\
Months & 10 & 19 & 76 \\
Weeks & 26 & 14 & 40 \\
Days & 15 & 20 & 68 \\
Fund Offshore & 16 & 32 & 63 \\
\hline \hline
\end{tabular}


Table 3

Summary Statistics of Smoothing Measures

This table presents summary statistics of the three smoothing measures used in the empirical analyses. The first measure is the monthly first order serial correlation $\left(\hat{\rho}_{1}\right)$ of reported returns, which we estimate over the entire history of returns available on either the Lipper-TASS, Hedge Fund Research, or CISDM databases. To estimate the other two measures, we follow Getmansky, Lo, and Makarov (2004) and assume that actual monthly performance innovations are independently and normally distributed, but are smoothed using a Moving Average model with two lags:

$$
\begin{gathered}
X_{t}=\theta_{0} \eta_{t}+\theta_{1} \eta_{t-1}+\theta_{2} \eta_{t-2} \\
1=\theta_{0}+\theta_{1}+\theta_{2} \\
\eta_{k} \sim \operatorname{Nor}\left(0, \sigma_{\eta}^{2}\right)
\end{gathered}
$$

We estimate the $\mathrm{MA}(2)$ coefficients using Maximum Likelihood and then transform the estimated coefficients by dividing each $\hat{\theta}_{i}$ by $1+\hat{\theta}_{1}+\hat{\theta}_{2}$ to normalize them. Our second smoothing measure is the first coefficient $\hat{\theta}_{0}$ from the above estimation. $\hat{\theta}_{0}$ represents the percentage of the month's actual performance innovation that is included in the reported return. Our third measure is the Herfindahl Index measure of the concentration of the $\theta_{k}$ weights:

$$
\xi=\sum_{j=0}^{2} \theta_{j}^{2}
$$

Lower values of $\xi$ represent greater smoothing. We winsorize all three measures to the $1^{\text {st }}$ and $99^{\text {th }}$

\begin{tabular}{|c|c|c|c|c|c|c|}
\hline Variable & Mean & Std. Dev. & Q1 & Median & Q3 & $\mathrm{N}$ \\
\hline Serial Correlation $\left(\hat{\rho}_{1}\right)$ & 0.247 & 0.196 & 0.111 & 0.223 & 0.402 & 260 \\
\hline Theta Coefficient $\left(\hat{\theta}_{0}\right)$ & 0.767 & 0.194 & 0.623 & 0.739 & 0.881 & 260 \\
\hline Smoothing Index $(\hat{\xi})$ & 0.694 & 0.301 & 0.475 & 0.595 & 0.808 & 260 \\
\hline Months & 79.996 & 36.868 & 56.000 & 72.000 & 97.500 & 260 \\
\hline
\end{tabular}
percentiles. Panel A presents summary statistics for the three smoothing measures and Panel B presents their Pearson correlations.

Panel A: Summary Statistics

Panel B: Pearson Correlations

\begin{tabular}{lccc}
\hline \hline & $\hat{\rho}_{1}$ & $\hat{\theta}_{0}$ & $\hat{\xi}$ \\
\cline { 2 - 4 } Serial Correlation $\left(\hat{\rho}_{1}\right)$ & 1.000 & -0.838 & -0.757 \\
Theta Coefficient $\left(\hat{\theta}_{0}\right)$ & & 1.000 & 0.960 \\
Smoothing Index $(\hat{\xi})$ & & & 1.000 \\
\hline \hline
\end{tabular}




\section{Table 4}

\section{Univariate Tests of Pricing Controls and Smoothing Measures}

This table presents means for the three smoothing measures classified by the pricing controls. Differences between means are tested using two-sided $t$ tests. Variable definitions for the pricing controls are provided in Table 1. Variable definitions for the smoothing measures are provided in Table 3.

\begin{tabular}{lccc}
\hline \hline & \multicolumn{3}{c}{ Mean } \\
\cline { 2 - 4 } Variable & $\hat{\rho}$ & $\hat{\theta_{0}}$ & $\hat{\xi}$ \\
\cline { 2 - 4 } Source of Prices: & & & \\
Manager Provided & 0.326 & 0.682 & 0.569 \\
Model Based & 0.268 & 0.747 & 0.661 \\
Dealer Quotes & 0.311 & 0.706 & 0.613 \\
OTC Quotes & $0.174^{\mathrm{a}, \mathrm{c}}$ & $0.876^{\mathrm{a}, \mathrm{b}, \mathrm{c}}$ & $0.846^{\mathrm{a}, \mathrm{b}, \mathrm{c}}$ \\
Exchange Quotes & $0.139^{\mathrm{a}, \mathrm{b}, \mathrm{c}}$ & $0.867^{\mathrm{a}, \mathrm{b}, \mathrm{c}}$ & $0.836^{\mathrm{a}, \mathrm{b}, \mathrm{c}}$ \\
& & & \\
Who Prices: & & & \\
Manager Only & 0.278 & 0.732 & 0.632 \\
Collaborative & 0.294 & 0.738 & 0.655 \\
Administrator Only & 0.234 & 0.772 & 0.702 \\
Dual/Triple Entity & $0.204^{\mathrm{e}}$ & $0.843^{\mathrm{d}, \mathrm{e}, \mathrm{f}}$ & $0.825^{\mathrm{d}, \mathrm{e}, \mathrm{f}}$ \\
& & & \\
NAV: & & & \\
Manager Involved & 0.270 & 0.758 & 0.680 \\
Manager Not Involved & 0.242 & 0.769 & 0.697 \\
Auditor: & & & \\
Not Ranked & & & \\
Ranked & 0.221 & 0.773 & 0.712 \\
& 0.254 & 0.765 & 0.689 \\
Administrator: & & & \\
Not Ranked & & & \\
Ranked & 0.251 & 0.763 & 0.691 \\
\hline \hline
\end{tabular}

a Significantly different from Manager Provided at the .05 level

b Significantly different from Model Based at the .05 level

c Significantly different from Dealer Quotes at the .05 level

d Significantly different from Manager Only at the .10 level

e Significantly different from Collaborative at the 10 level

f Significantly different from Administrator Only at the .10 level 
Table 5

\section{Benchmark Specification}

This table presents ordinary least squares regressions that use the smoothing measures as the dependent variable, but exclude the pricing controls. The omitted categories are Miscellaneous, 1-39 Positions, and Days. Standard errors are reported in parentheses. Variable definitions for the smoothing measures are provided in Table 3.

\begin{tabular}{|c|c|c|c|}
\hline Dependent Variable: & $\hat{\rho}$ & $\hat{\theta}_{0}$ & $\hat{\xi}$ \\
\hline \multirow[t]{2}{*}{ Convertible Arbitrage } & $0.288^{* * *}$ & $-0.280^{* * *}$ & $-0.398^{* * *}$ \\
\hline & $(0.074)$ & $(0.077)$ & $(0.121)$ \\
\hline \multirow[t]{2}{*}{ Emerging Markets } & $0.134^{*}$ & $-0.188^{* *}$ & $-0.328^{* * *}$ \\
\hline & $(0.072)$ & $(0.074)$ & $(0.118)$ \\
\hline \multirow[t]{2}{*}{ Equity Market Neutral } & -0.030 & -0.003 & -0.048 \\
\hline & $(0.089)$ & $(0.092)$ & $(0.146)$ \\
\hline \multirow[t]{2}{*}{ Event Driven } & $0.166^{* * *}$ & $-0.198^{* * *}$ & $-0.292^{* * *}$ \\
\hline & $(0.060)$ & $(0.061)$ & $(0.097)$ \\
\hline \multirow[t]{2}{*}{ Fixed Income Arbitrage } & $0.124^{*}$ & $-0.175^{* *}$ & $-0.302^{* * *}$ \\
\hline & $(0.070)$ & $(0.072)$ & $(0.114)$ \\
\hline \multirow[t]{2}{*}{ Global Macro } & -0.049 & -0.027 & -0.052 \\
\hline & $(0.065)$ & $(0.067)$ & $(0.106)$ \\
\hline \multirow[t]{2}{*}{ Long/ Short Equity } & -0.002 & -0.088 & $-0.174^{*}$ \\
\hline & $(0.057)$ & $(0.059)$ & $(0.094)$ \\
\hline \multirow[t]{2}{*}{ Multi-Strategy } & $0.172^{* * *}$ & $-0.210^{* * *}$ & $-0.302^{* * *}$ \\
\hline & $(0.062)$ & $(0.064)$ & $(0.101)$ \\
\hline \multirow[t]{2}{*}{ Fund of Funds } & $0.128^{*}$ & $-0.169^{* * *}$ & $-0.255^{* *}$ \\
\hline & $(0.077)$ & $(0.064)$ & $(0.101)$ \\
\hline \multirow[t]{2}{*}{ 1000+ Positions } & -0.018 & -0.007 & -0.060 \\
\hline & $(0.077)$ & $(0.080)$ & $(0.126)$ \\
\hline \multirow[t]{2}{*}{ 200-999 Positions } & -0.014 & -0.020 & -0.050 \\
\hline & $(0.058)$ & $(0.060)$ & $(0.094)$ \\
\hline \multirow[t]{2}{*}{ 100-199 Positions } & 0.029 & -0.030 & -0.049 \\
\hline & $(0.038)$ & $(0.039)$ & $(0.061)$ \\
\hline \multirow[t]{2}{*}{ 40-99 Positions } & 0.007 & 0.004 & 0.004 \\
\hline & $(0.027)$ & $(0.028)$ & $(0.044)$ \\
\hline \multirow[t]{2}{*}{ Years } & 0.004 & -0.016 & -0.034 \\
\hline & $(0.045)$ & $(0.047)$ & $(0.074)$ \\
\hline \multirow[t]{2}{*}{ Quarters } & 0.019 & -0.031 & -0.044 \\
\hline & $(0.044)$ & $(0.045)$ & $(0.072)$ \\
\hline \multirow[t]{2}{*}{ Month } & 0.003 & 0.033 & 0.046 \\
\hline & $(0.051)$ & $(0.052)$ & $(0.083)$ \\
\hline \multirow[t]{2}{*}{ Weeks } & -0.004 & -0.033 & -0.045 \\
\hline & $(0.056)$ & $(0.058)$ & $(0.092)$ \\
\hline \multirow[t]{2}{*}{ Fund Offshore } & 0.022 & -0.016 & -0.014 \\
\hline & $(0.031)$ & $(0.032)$ & $(0.050)$ \\
\hline \multirow[t]{2}{*}{ Intercept } & $0.133^{*}$ & $0.933^{* * *}$ & $0.958^{* * *}$ \\
\hline & $(0.071)$ & $(0.073)$ & $(0.116)$ \\
\hline $\mathrm{R}^{2}$ & 0.243 & 0.177 & 0.140 \\
\hline Adj. $\mathrm{R}^{2}$ & 0.186 & 0.116 & 0.076 \\
\hline $\mathrm{p}$ Value & 0.000 & 0.000 & 0.004 \\
\hline Number of Funds & 260 & 260 & 260 \\
\hline
\end{tabular}

$* * *, * * *$ Significantly different from zero at the .01, .05, and .10 level, 


\section{Table 6}

\section{Multivariate Tests of Pricing Controls and Smoothing Measures}

This table presents multivariate tests of the association between the pricing controls and the smoothing measures. Regressions are estimated using ordinary least squares and include the control variables used in Table 5. Standard errors are reported in parentheses. The omitted pricing control categories are Exchange Quotes and Dual/Triple Entity. Panel A present results for Serial Correlation. Panel B presents results for Theta Coefficient. Panel C presents results for the Smoothing Index

Panel A: Serial Correlation

\begin{tabular}{llllll}
\multicolumn{7}{c}{ Dependent Variable: $\hat{\rho}$} \\
\hline$(1)$ & $(2)$ & $(3)$ & $(4)$ & $(5)$ & $(6)$ \\
\hline
\end{tabular}

Source of Prices:

Manager Provided

$0.142^{* * *}$

$(0.046)$

Model Based

Dealer Quotes

OTC Quotes

Who Prices:

Manager Only

Collaborative

Administrator Only

NAV Manager

Auditor Not Ranked

Administrator Not Ranked$$
\mathrm{R}^{2}
$$

Adj. $R^{2}$

$\mathrm{p}$ Value

Number of Funds

Controls Included

$$
\begin{gathered}
0.054 \\
(0.047) \\
0.062 \\
(0.050) \\
0.039 \\
(0.041)
\end{gathered}
$$

$0.141^{\text {*** }}$

(0.049)

$0.082^{*}$

(0.046)

$0.081^{\text {** }}$

$(0.037)$

0.073

(0.059)

0.036

(0.051)

0.028

(0.052)

0.031

(0.041)

$0.002-0.004$

$(0.034)$

$-0.032$

$(0.043)$

$-0.036$

(0.028)

$-0.012 \quad-0.011$

$(0.025)$

$(0.025)$

\begin{tabular}{cccccc}
0.277 & 0.249 & 0.243 & 0.247 & 0.244 & 0.284 \\
0.210 & 0.182 & 0.183 & 0.187 & 0.184 & 0.198 \\
0.000 & 0.000 & 0.000 & 0.000 & 0.000 & 0.000 \\
260 & 260 & 260 & 260 & 260 & 260 \\
Yes & Yes & Yes & Yes & Yes & Yes \\
\hline
\end{tabular}

***,**** Significantly different from zero at the .01, .05, and .10 level, 
Table 6 (continued)

\section{Multivariate Tests of Pricing Controls and Smoothing Measures}

Panel B: Theta Coefficient

\begin{tabular}{cccccc}
\multicolumn{7}{c}{ Dependent Variable: $\hat{\theta}_{0}$} \\
\hline$(1)$ & $(2)$ & $(3)$ & $(4)$ & $(5)$ & $(6)$ \\
\hline
\end{tabular}

Source of Prices:

Manager Provided

$-0.202^{* * *}$

(0.047)

Model Based

$-0.106^{* *}$

(0.044)

Dealer Quotes

$-0.126^{* * *}$

(0.035)

OTC Quotes

$-0.024$

(0.059)

$-0.195^{* * *}$

(0.049)

$-0.110^{* *}$

(0.046)

$-0.125^{* * *}$

(0.037)

$-0.031$

(0.059)

Who Prices:

Manager Only

$-0.115^{* *}$

$-0.087^{*}$

Collaborative

(0.048)

(0.051)

$-0.101^{*}$

$-0.042$

(0.051)

(0.052)

Administrator Only

$-0.083^{* *}$

$-0.068$

(0.042)

(0.042)

NAV Manager

0.0002

0.020

(0.036)

(0.043)

Auditor Not Ranked

Administrator Not Ranked

0.001

0.004

$(0.029)$

(0.029)

\begin{tabular}{|c|c|c|c|c|c|c|}
\hline \multicolumn{5}{|c|}{ Administrator Not Ranked } & $\begin{array}{c}-0.0004 \\
(0.026) \\
\end{array}$ & $\begin{array}{r}0.003 \\
(0.026) \\
\end{array}$ \\
\hline $\mathrm{R}^{2}$ & 0.246 & 0.198 & 0.177 & 0.177 & 0.177 & 0.258 \\
\hline Adj. $\mathrm{R}^{2}$ & 0.176 & 0.128 & 0.112 & 0.112 & 0.112 & 0.169 \\
\hline p Value & 0.000 & 0.000 & 0.000 & 0.000 & 0.000 & 0.000 \\
\hline Number of Funds & 260 & 260 & 260 & 260 & 260 & 260 \\
\hline Controls Included & Yes & Yes & Yes & Yes & Yes & Yes \\
\hline
\end{tabular}

***,**** Significantly different from zero at the $0.01,0.05$, and 0.10 level 
Table 6 (continued)

\section{Multivariate Tests of Pricing Controls and Smoothing Measures}

Panel C: Smoothing Index

\begin{tabular}{cccccc}
\multicolumn{7}{c}{ Dependent Variable: $\hat{\xi}$} \\
\hline$(1)$ & $(2)$ & $(3)$ & $(4)$ & $(5)$ & $(6)$ \\
\hline
\end{tabular}

Source of Prices:

Manager Provided

$-0.323^{* * *}$

(0.075)

Model

$-0.163^{* *}$

$(0.070)$

Dealer Quotes

$-0.202^{* * *}$

$(0.056)$

OTC Quotes

$-0.050$

(0.093)

$-0.307^{* * *}$

(0.078)

$-0.165^{* *}$

(0.073)

$-0.196^{* * *}$

(0.059)

$-0.059$

(0.094)

Who Prices:

Manager Only

$-0.198^{* * *}$

$-0.161^{* *}$

(0.076)

(0.081)

Collaborative

$-0.165^{* *}$

$-0.074$

(0.081)

(0.083)

Administrator Only

$-0.131^{* *}$

$-0.105$

(0.066)

(0.066)

NAV Manager

$-0.002$

0.043

Auditor Not Ranked

(0.056)

(0.068)

0.009

0.015

(0.046)

(0.046)

Administrator Not Ranked

0.213

0.140

0.165

0.092

0.000

0.002

260

260

Yes

Yes

\begin{tabular}{rrrr}
0.140 & 0.140 & 0.140 & 0.228 \\
0.072 & 0.072 & 0.072 & 0.135 \\
0.007 & 0.007 & 0.007 & 0.000 \\
260 & 260 & 260 & 260 \\
Yes & Yes & Yes & Yes \\
\hline
\end{tabular}

***,**** Significantly different from zero at the .01, .05, and .10 level 
Table 7

\section{Within the Event Driven Style}

This table presents for Event Driven funds the means of the three smoothing measures classified by the pricing controls. No Event Driven funds in the sample source prices from OTC Quotes. Differences between means are tested using two-sided $t$ tests. Variable definitions for the pricing controls are provided in Table 1. Variable definitions for the smoothing measures are provided in Table 3.

\begin{tabular}{lccc}
\hline \hline & \multicolumn{3}{c}{ Mean } \\
\cline { 2 - 4 } Variable & $\hat{\rho}$ & $\hat{\theta}_{0}$ & $\hat{\xi}$ \\
\cline { 2 - 4 } Source of Prices: & & & \\
Manager Provided & 0.368 & 0.615 & 0.496 \\
Model Based & $0.104^{\mathrm{a}}$ & $0.932^{\mathrm{a}}$ & $0.979^{\mathrm{a}}$ \\
Dealer Quotes & $0.354^{\mathrm{b}}$ & $0.698^{\mathrm{b}}$ & $0.601^{\mathrm{b}}$ \\
Exchange Quotes & 0.280 & $0.837^{\mathrm{a}}$ & $0.843^{\mathrm{a}}$ \\
& & & \\
Who Prices: & & & \\
Manager Only & 0.384 & 0.645 & 0.523 \\
Collaborative & 0.343 & 0.732 & 0.661 \\
Administrator Only & 0.316 & 0.661 & 0.542 \\
Dual/Triple Entity & 0.280 & 0.799 & $0.795^{\mathrm{c}, \mathrm{d}}$ \\
& & & \\
Number of Funds & 38 & & \\
\hline \hline
\end{tabular}

a Significantly different from Manager Provided at the .10 level

b Significantly different from Model Based at the .05 level

c Significantly different from Manager Only at the .10 level

d Significantly different from Administrator Only at the .10 level 


\section{Table 8 \\ Manager Skill and Pricing Controls}

This table presents mean alphas tabulated the by the funds' pricing controls. The alphas estimated over the life the fund using Fung and Hsieh's eight factor model: the returns of S\&P 500, the small capitalization minus large capitalization factor, the bond trend following factor, the currency trend following factor, the commodity trend following factor, the stock index trend following factor, the bond market factor, and the credit spread factor.

\begin{tabular}{lc}
\hline \hline & Mean \\
\cline { 2 - 2 } Variable & $\hat{\alpha}$ \\
\cline { 2 - 2 } Source of Prices: & \\
Manager Provided & 0.00545 \\
Model Based & $0.01288^{\mathrm{a}, \mathrm{b}}$ \\
Dealer Quotes & $0.00882^{\mathrm{a}, \mathrm{b}}$ \\
OTC Quotes & $0.00561^{\mathrm{b}}$ \\
Exchange Quotes & $0.00833^{\mathrm{a}, \mathrm{b}}$ \\
& \\
Who Prices: & 0.00916 \\
Manager Only & $0.01210^{\mathrm{c}}$ \\
Collaborative & $0.00756^{\mathrm{d}}$ \\
Administrator Only & $0.00809^{\mathrm{d}}$ \\
Dual/Triple Entity & \\
\hline \hline & \\
a Significantly different from Manager Provided at the .05 level \\
b Significantly different from Model Based at the .05 level \\
c Significantly different from Manager Only at the .05 level \\
d Significantly different from Collaborative at the .05 level \\
e Significantly different from Administrator Only at the .05 level
\end{tabular}




\section{Table 9}

\section{Before and After the Due Diligence Report}

This table presents multivariate tests of the association between the pricing controls and the smoothing measures estimated using returns reported before and after the due diligence report was completed. Regressions are estimated using ordinary least squares and include the control variables used in Table 5. Standard errors are reported in parentheses. The omitted pricing control categories are Exchange Quotes and Dual/Triple Entity.

Panel A: Before the Due Diligence Report

\begin{tabular}{|c|c|c|c|c|c|c|}
\hline \multirow[t]{2}{*}{ Dependent Variable: } & \multicolumn{2}{|c|}{$\hat{\rho}$} & \multicolumn{2}{|c|}{$\hat{\theta}_{0}$} & \multicolumn{2}{|c|}{$\hat{\xi}$} \\
\hline & $(1)$ & $(2)$ & (3) & $(4)$ & $(5)$ & (6) \\
\hline \multicolumn{7}{|l|}{ Source of Prices: } \\
\hline \multirow[t]{2}{*}{ Manager Provided } & $0.092^{*}$ & & -0.091 & & $-0.205^{* *}$ & \\
\hline & $(0.052)$ & & $(0.063)$ & & $(0.100)$ & \\
\hline \multirow[t]{2}{*}{ Model Based } & 0.043 & & $-0.094)$ & & $-0.188^{*}$ & \\
\hline & $(0.057)$ & & $(0.068$ & & $(0.109)$ & \\
\hline \multirow[t]{2}{*}{ Dealer Quotes } & 0.055 & & $-0.124^{*}$ & & $-0.234^{* * *}$ & \\
\hline & $(0.043)$ & & $(0.051)$ & & $(0.082)$ & \\
\hline \multirow[t]{2}{*}{ OTC Quotes } & 0.036 & & -0.062 & & -0.079 & \\
\hline & $(0.067)$ & & $(0.081)$ & & $(0.128)$ & \\
\hline \multicolumn{7}{|l|}{ Who Prices: } \\
\hline \multirow[t]{2}{*}{ Manager Only } & & -0.053 & & 0.013 & & -0.038 \\
\hline & & $(0.065)$ & & $(0.079)$ & & $(0.127)$ \\
\hline \multirow[t]{2}{*}{ Collaborative } & & -0.043 & & -0.007 & & -0.034 \\
\hline & & $(0.065)$ & & $(0.079)$ & & $(0.126)$ \\
\hline \multirow[t]{2}{*}{ Administrator Only } & & -0.049 & & 0.007 & & -0.023 \\
\hline & & $(0.058)$ & & $(0.071)$ & & $(0.114)$ \\
\hline $\mathrm{R}^{2}$ & 0.289 & 0.276 & 0.283 & 0.252 & 0.277 & 0.233 \\
\hline Adj. $R^{2}$ & 0.176 & 0.166 & 0.169 & 0.139 & 0.161 & 0.117 \\
\hline $\mathrm{p}$ Value & 0.001 & 0.001 & 0.001 & 0.003 & 0.001 & 0.009 \\
\hline Number of Funds & 161 & 161 & 161 & 161 & 161 & 161 \\
\hline Controls Included & Yes & Yes & Yes & Yes & Yes & Yes \\
\hline
\end{tabular}

******* Significantly different from zero at the .01, .05, and .10 level, 
Table 9 (continued)

Before and After the Due Diligence Report

Panel B: After the Due Diligence Report

\begin{tabular}{|c|c|c|c|c|c|c|}
\hline \multirow[t]{2}{*}{ Dependent Variable: } & \multicolumn{2}{|c|}{$\hat{\rho}$} & \multicolumn{2}{|c|}{$\hat{\theta}_{0}$} & \multicolumn{2}{|c|}{$\hat{\xi}$} \\
\hline & $(1)$ & $(2)$ & (3) & (4) & (5) & (6) \\
\hline \multicolumn{7}{|l|}{ Source of Prices: } \\
\hline Manager Provided & $\begin{array}{l}0.187^{* * *} \\
(0.057)\end{array}$ & & $\begin{array}{l}-0.280^{* * *} \\
(0.062)\end{array}$ & & $\begin{array}{l}-0.481^{* * *} \\
(0.100)\end{array}$ & \\
\hline Model Based & $\begin{array}{c}0.086^{*} \\
(0.052)\end{array}$ & & $\begin{array}{l}-0.150^{* * *} \\
(0.056)\end{array}$ & & $\begin{array}{l}-0.272^{* * * *} \\
(0.091)\end{array}$ & \\
\hline Dealer Quotes & $\begin{array}{c}0.078^{*} \\
(0.041)\end{array}$ & & $\begin{array}{l}-0.139^{* * *} \\
(0.045)\end{array}$ & & $\begin{array}{l}-0.237^{* * * *} \\
(0.073)\end{array}$ & \\
\hline OTC Quotes & $\begin{array}{l}-0.033 \\
(0.071)\end{array}$ & & $\begin{array}{c}0.090 \\
(0.078)\end{array}$ & & $\begin{array}{c}0.132 \\
(0.125)\end{array}$ & \\
\hline \multicolumn{7}{|l|}{ Who Prices: } \\
\hline Manager Only & & $\begin{array}{c}0.029 \\
(0.058)\end{array}$ & & $\begin{array}{l}-0.117^{*} \\
(0.064)\end{array}$ & & $\begin{array}{l}-0.248^{* *} \\
(0.104)\end{array}$ \\
\hline Collaborative & & $\begin{array}{c}0.037 \\
(0.064)\end{array}$ & & $\begin{array}{l}-0.109^{*} \\
(0.071)\end{array}$ & & $\begin{array}{l}-0.241^{* *} \\
(0.115)\end{array}$ \\
\hline Administrator Only & & $\begin{array}{c}0.023 \\
(0.051) \\
\end{array}$ & & $\begin{array}{l}-0.098 \\
(0.056)\end{array}$ & & $\begin{array}{r}0.165^{*} \\
(0.091)\end{array}$ \\
\hline $\mathrm{R}^{2}$ & 0.264 & 0.221 & 0.238 & 0.156 & 0.233 & 0.150 \\
\hline Adj. $\mathrm{R}^{2}$ & 0.182 & 0.136 & 0.154 & 0.067 & 0.148 & 0.061 \\
\hline $\mathrm{p}$ Value & 0.000 & 0.000 & 0.000 & 0.025 & 0.000 & 0.036 \\
\hline Number of Funds & 222 & 222 & 222 & 222 & 222 & 222 \\
\hline Controls Included & Yes & Yes & Yes & Yes & Yes & Yes \\
\hline
\end{tabular}

******** Significantly different from zero at the $.01, .05$, and .10 level, 